\title{
Využití algoritmů při profilování v trestním rízení a důsledky pro lidská práva*
}

\section{The Use of Algorithms for Profiling in Criminal Proceedings and Implications for Human Rights}

\author{
Eva Fialová**
}

\begin{abstract}
Abstrakt
Algoritmy nabrazuji činnosti, keteré drưve vykonávali lidé. Jednou z. tèchto činností je soudní rozhodování založené na algoritmech. Obecně se prédpokládá, že algoritmické rozhodování, na rozdíl od toho lidského, postrádá prèdsudky a predpojatosti. Tento predpoklad je problematický ve dvou momentech. Za prvé, algoritmus rozhoduje podle predem stanovených kritérii a hodnot. Tyto hodnoty určuji lidé, kteři mohou mezi predem stanovená kritéria zahrnout ta, která odpovidají jejich predsudküm. Za drubé, některé algoritmy mohou mit schopnost učit se, což znamená, že vygenerované výsledky jsou prizprisobeny predchozím výsledkim, které byly v minulosti uprednostnèny. Ǔ̌ivatelé mohou mit možnost zuolit výsledky, které odpovidají jejich názoru, které však mohou být založeny na prèdsudcich. Ve Spojenjých státech a také v nèketerých evropských zemich již soudy použivaji algoritmus k posouzeni, zda je pravděpodobné, žze obvinèný (resp. odsonz̨ený) spáchá v budoucnosti jiný trestný čin. Soudce neroz̧oduje na základě okolností prípadu a individuálnich charakteristik obvinèného. Soudce rozhoduje misto toho na podkladě profilu. Profily pachateli jsou sestaveny na základě osobnich údaju pachatelì, pričemž nékteré z. téchto údaju mohou mit povahu biometrického údaje. Algoritmické rozhodováni založené na profilováni vyvolává obavy ze zásabu do práv obvinèného v soudním rǐzeni, konkétné zákeąu diskriminace a právu na spravedlivý proces.
\end{abstract}

\section{Klíčová slova}

Algoritmus; biometrické údaje; diskriminace; profilování; spravedlivý proces; trestní rǐzení.

\section{Abstract}

Algorithms are replacing activities that have previously been performed by humans. One of these activities is judicial decision making based on algorithms. It is generally assumed that algorithmic decision making, as opposed to the human decision making, is free from prejudice and bias. This assumption is problematic in two ways. Firstly, the algorithm decides according to pre-specified criteria and values. These values are chosen by humans who may include among the predefined criteria the criteria that correspond to their prejudices and preconceptions. Secondly, some algorithms may have their own learning ability, which means that the generated results are adapted to the previous ones to which were given preference in the past. The users may have the possibility to choose precedents that correspond with their point of view, which may be based on prejudice. In the United States and also in some European countries an algorithm is already being used by courts to assess whether or not it is likely that the accused (or condemned) will commit another crime

\footnotetext{
* Př́spěvek vznikl za podpory projektu Grantové agentury České republiky č. 16-26910S s názvem Biometrické údaje a jejich zvláštní právní ochrana (Biometric Data and Their Specific Legal Protection).

** JUDr. Mgr. Eva Fialová, LL.M., Ph.D., Ústav státu a práva AV ČR, v. v. i. / Institute of State and Law of the Czech Academy of Science / E-mail: eva.fialova@ilaw.cas.cz
} 
in the future. The judge does not decide based on the circumstances of the case and individual characteristics of the accused. The judge decides instead on the basis of a profile. The profiles are based on personal data of the offender. Some of those data have a character of biometric data. The algorithmic decision making based on profiling raises concerns about the rights of the accused in the judicial proceedings, namely the probibition of discrimination and the right to a fair trial.

\section{Keywords}

Algorithms; Biometric Data; Criminal Proceedings; Discrimination; Profiling; Fair Trial.

\section{Úvod}

V současné době bývá analytická práce nejrůznějšího charakteru vykonávána pomocí výpočetní techniky, která používá sofistikované algoritmy. V důsledku toho dochází $\mathrm{k}$ jevu, že tyto algoritmy částečně nebo úplně provádí nejrůznější činnosti dříve vykonávané člověkem. ${ }^{1}$ Zakladatel kybernetiky Norbert Wiener mluví o tomto typu mechanizace jako o typu nahrazující lidské rozhodování. Přestože Wiener nepredpokládal, že je možné nahradit složité rozhodování člověka s mnoha proměnnými rozhodováním mechanizovaným, ${ }^{2}$ ukázalo se, že opak je pravdou, nebot’ mechanizované rozhodování je přítomno v nejrůznějších oblastech běžného života. ${ }^{3}$

Slovo algoritmus pochází odvozením ze jména perského matematika Al-Chorezmího a znamená metodu systematického a automatizovaného výpočtu. Algoritmus je soubor př́kazů, které musí být provedeny, aby se dosáhlo požadovaného výsledku nebo řešení. Snaha o systematický a automatizovaný výpočet není jev, který by byl typický pouze pro dnešní dobu. Nová je kapacita výpočetní techniky a algoritmy se schopností učení, tj. algoritmy, jejichž výstupy se přizpůsobují změnám, aniž by jim byl dán konkrétní pokyn se změně přizpůsobit. ${ }^{5}$ Uživatel softwaru, jehož je takový algoritmus součástí, neví, s jakými proměnnými algoritmus při generování výstupů pracuje, jaká vstupní data algoritmus použil a jaká naopak opomenul.

V tomto článku se budeme zabývat rozhodováním v trestním řízení, v němž se využívá algoritmů k posouzení rizikovosti pachatele (obviněného, obžalovaného, resp. odsouzeného) s ohledem na pravděpodobnost recidivy. ${ }^{6}$ Algoritmy se tedy využívají ke kategorizaci pachatelů. Ke kategorizaci pachatelů dochází na základě jejich skutečných

1 STEINER, Christopher. Automate This. How Algorithms Came to Rule Our World. London: Penguin Books, 2012, s. 11. ISBN 978-1-101-57215-3.

2 WIENER, Norbert. The Human Use of Human Beings: cybernetics and society. London: Free Association Books, 1989, s. 159. ISBN 1-85343-075-7.

3 STEINER, op. cit., s. 41.

4 Ibid, s. 50 .

5 Např. Machine Learning. What it is \& why it matters. SAS [online].[cit. 30. 4. 2017]. Dostupné z: https:// www.sas.com/it_it/insights/analytics/machine-learning.html

6 V tomto článku používáme pojem recidiva pro opakování trestného činu nebo trestné činnosti. 
či domnělých psychologických rysů vyvozených z předchozího chování těchto pachatelů a dalších údajů o jejich osobě. Profily pachatelů založené na psychologických rysech jsou dle Pracovní skupiny 29 biometrickými osobními údaji. Jedná se o tzv. druhou generaci biometrických údajů, kde cílem zpracovávání není identifikovat osobu, ale číst její mysl. ${ }^{8}$ Profil pachatele zaměřený na predikci jeho budoucího kriminogenního chování je v tomto smyslu tzv. behaviorálním biometrickým profilem. ${ }^{9}$ Tento behaviorální biometrický profil je tvořen jak nebiometrickými údaji (bydliště, věk, vzdělánî) tak údaji biometrickými (psychologické rysy pachatele). ${ }^{10}$

Využití algoritmů v procesu rozhodování v trestním řízení není pouhou teorií. Tento druh rozhodování se již v současnosti používá pro stanovení délky trestu odnětí svobody, pro určení, zda obžalovanému uložit podmíněný či nepodmíněný trest odnětí svobody, či pro rozhodnutí, zda odsouzeného podmínečně propustit z výkonu trestu. ${ }^{11}$

Důvodem, proč se rozhodování na podkladě algoritmu ve výše uvedených případech využívá, může být snaha o přesné a objektivní rozhodování bez předsudků a zaujatostí, které jsou lidem vlastní. ${ }^{12}$ Podle Kate Crawford se algoritmy často rozumí výpočetní nástroj, který autokraticky rozhoduje mezi proměnnými a vytvář́ jeden výstup. Důsledkem toho je, že výstupy jsou považovány za racionální, oproštěné od subjektivních představ a požadavků. ${ }^{13}$

Cílem tohoto článku je popsat rozhodování s využitím algoritmu v trestním rrízení, jakož i analyzovat rizika spojená s využitím algoritmu při rozhodování, zejména důsledků pro základní lidská práva a svobody. V tomto článku budeme používat pojem algoritmické rozhodování pro rozhodnutí učiněného na podkladě výstupu vygenerovaného algoritmem.

7 PRACOVNÍ SKUPINA 29. Stanovisko č.3/2012 k vývoji biometrických technologii (WP 193). S. 4. Dostupné z: https://www.uoou.cz/files/wp_193.pdf

8 DE HERT, Paul. Biometrics and the Challenge to Human Rights in Europe. In: CAMPISI, Patrizio. Security and Privacy in Biometrics. Dordrecht: Springer, 2013, s. 406. ISBN 9781447152293.

9 YANNOPOULOS, Angelos, Vassiliki ANDRONIKOU a Theodora VARVARIGOU. Behavioural Biometric Profiling and Ambient Intelligence. In: HILDEBRANDT, Mireille a Gutwirth SERGE. Profiling the European Citizen. Cross-Disciplinary Perspectives. Dordrecht: Springer, 2008, s. 90. ISBN 9781402069130.

10 Administrative Office of the United States Courts Office of Probation and Pretrial Services. An Overview of the Federal Post Conviction Risk Assessment. Uscourts [online]. 2011, s. 1 [cit. 25. 5. 2016]. Dostupné z: www.uscourts.gov/file/2749/download

11 Napr. ROUVROY, Antoinette. L'algorithmen'est „pas un système de prediction mais d'intervention“. Medipart [online]. 2015, s. 1 [cit. 30. 4. 2016]. Dostupné z: https://www.academia.edu/12603930/Lalgorithme_nest_pas_un_système_de_prédiction_mais_d_intervention_Entretien_réalisé_par_Jérôme_ Hourdeaux_pour_Mediapart_25_mai_2015; nebo CRAWFORD, Kate. Can An Algorithm be Agonistic? Scenes of Contest in Calculated Publics [online]. 2016, s. 2 [cit. 30. 4. 2016]. Dostupné z: http://lawdigitalcommons.bc.edu $/$ cgi $/$ viewcontent.cgi?article $=3351 \&$ context $=$ bclr

12 ROTH, Andrea. Trial by Machine. Georgetown Law Journal [online]. 2016, roč. 104, č. 5 , s. 6 [cit. 30. 4. 2016]. Dostupné z: http://papers.ssrn.com/sol3/papers.cfm?abstract_id=2743800

13 CRAWFORD, op. cit. 


\section{Algoritmické rozhodování v trestním řízení}

\subsection{Algoritmické rozhodování a aplikace práva}

Základem soudní moci je podle Owna Fisse proces, jehož výkonem jsou pověřeni soudci, kteří vykládají texty právní předpisů. Fiss rozlišuje dva aspekty soudního procesu. Prvním z nich je nezávislost. Jako druhý aspekt spatřuje Fiss povinnost soudce slyšet účastníky řízení. Tento aspekt soudnictví je podle Fisse v ohrožení, nebot’ dochází $\mathrm{k}$ byrokratizaci soudního procesu. ${ }^{14}$

„Je povinností soudce, aby se zapojil do zulástního dialogu, a sice naslouchal všem stí̌nostem, slyšel v̌̌echny dotčené a uvedl di̛vody svého rozhodnutí. Svým podpisem pod rozsudkem nebo stanoviskem soudce ujištuje účastniky řżeni o tom, že se plněpodillel na tomto procesu a prébírá individuálni odpovědnost za své rozhodnuti. Akceptujeme soudni pravomoc za těchto podminek, a proto byrokratizace vyvolává obavu, že podpis soudce je jen podvod a že soudci vykonávaji pravomoc, aniž by byly skutečné rapojeni do dialogu, z nèhožjejich autorita vyplývá."15

Při soudním rozhodování prováděném pouze na základě algoritmu není nutné slyšet účastníky řízení nebo svědky. Soudce nemá důvod zajímat se o individuální okolnosti jednotlivého prrípadu, nebot' algoritmus pracuje jen s předdefinovanými hodnotami. Soudci stačí, či se mu nedostává jiné alternativy, než zadat do systému určité hodnoty, které jsou sice charakteristické pro daný případ, nicméně jsou omezené pouze na předdefinované kategorie. Individuální aspekty případu, které není možné přiřadit pod některou z předdefinovaných kategorií, jsou při rozhodování opomenuty.

České trestní právo zná mnoho ustanovení, která činí soud povinným zvážit podle okolností konkrétního př́padu, zda jsou přítomny podmínky pro použití určité právní normy, či jakým zpo̊sobem bude normu interpretovat a aplikovat. Nemožnost přihlédnout $\mathrm{k}$ individuálním okolnostem př́padu při algoritmickém rozhodování může mít za následek porušení základních zásad trestního práva.

Jedna z nejdůležitějších zásad trestního práva je subsidiarita trestní represe a princip ultima ratio trestní represe vyjádřené v \12 odst. 2 zákona č. 40/2009 Sb., trestní zákoník (dále jen „TZ“). Podle tohoto ustanovení lze trestní odpovědnost pachatele a trestněprávní důsledky s ní spojené uplatňovat jen $\mathrm{v}$ př́padech společensky škodlivých, ve kterých nepostačuje uplatnění odpovědnosti podle jiného právního předpisu. Trestní odpovědnost pachatele je krajním prostředkem ochrany společenských hodnot. ${ }^{16}$

14 FISS, Owen M. The Bureaucratization of the Judiciary. Faculty Scholarship Series. Paper 1216 [online]. 1983, s. 1443 [cit. 30. 4. 2016]. Dostupné z: http://digitalcommons.law.yale.edu/cgi/viewcontent. cgi?article $=2205 \&$ context $=$ fss_papers

15 Ibid.

16 ŠÁMAL, Pavel a kol. Trestní quákoník. I. Obecná část (』 1-139). 2. vyd. Praha: C. H. Beck, 2012, s. 115. ISBN 978-80-7400-428-5. 
„ZZ] zásady subsidiarity trestní represe plyne, že trestnèprávni rešeni prédstavuje krajní prostředek (ultima ratio) pro zákonodárce, ale i pro soudce, státní zástupce a policii, kdyžpostulát ultima ratio má nepochybnè význam i pro interpretaci trestnèprávních norem a plyne z něbo, že trestnými činy mohou být pouze závažnějsí priphady protispolečenských jednáni. Jen disledné respektováni principu ultima ratio zaručuje, že omezeni áakladnich práv fyzických a právnických osob v disledku trestnich sankeci je možno považovat za proporcionálni s účelem trestního práva hmotnébo sledovaným trestním řz̧enim." ${ }^{\text {"17 }}$

Pojem společenské škodlivosti není podle Šámala trestním zákoníkem záměrně definován $z$ důvodů možnosti zhodnocení okolností konkrétního případu orgánem činným v trestním řízení. ${ }^{18}$ Podle stanoviska trestního kolegia Nejvyššího soudu České republiky ${ }^{19}$ není společenská škodlivost zákonným znakem trestného činu, protože má svưj význam jen jako jedno z hledisek pro uplatňování zásady subsidiarity trestní represe. Společenskou škodlivost podle tohoto stanoviska Nejvyššího soudu dokonce ani nelze posuzovat obecně, nýbrž naopak konkrétně u každého spáchaného méně závažného trestného činu, u něhož je nutné ji zhodnotit s ohledem na intenzitu naplnění kritérií uvedených v \39 odst. 2 TZ, a to ve vztahu ke všem znakům zvažované skutkové podstaty trestného činu a dalším okolnostem prrípadu. Kritérii uvedenými v \39 odst. 2 TZ jsou zejména význam chráněného zájmu, který byl činem dotčen, způsob provedení činu a jeho následky, okolnosti, za kterých byl čin spáchán, osoba pachatele, míra jeho zavinění a jeho pohnutka, záměr nebo cíl. Výčet v tomto ustanovení je demonstrativní. Kritéria pro posouzení společenské škodlivosti mohou být tedy podle okolností prípadu i jiná. K zásadě subsidiarity trestní represe a principu ultima ratio se již mnohokrát vyjádrril Ústavní soud. Povaha trestního práva jako ultima ratio je dle názoru Ústavního soudu především reflexí principu proporcionality, který tento soud považuje za výraz demokratického právního státu. ${ }^{20}$

V př́padě, že obecné soudy podle judikatury Ústavního soudu zásadu subsidiarity trestní represe neaplikují, ačkoliv skutkové okolnosti svědčí o tom, že k tomu byly splněny podmínky, je podle tohoto soudu porušen ústavní princip nullum crimen, nulla poena sine lege zakotvený v čl. 39 Listiny základních práv a svobod („,dále jen: „Listina“). ${ }^{21}$

Výstižně se k zásadě subsidiarity trestní represe vyjádřil i Městský soud v Praze. ${ }^{22}$ Podle tohoto soudu je trestněprávní kvalifikace určitého činu jako trestného činu krajním

17 ŠÁMAL, Pavel a kol. Trestní zákoník I. Obecná část (』 1-139). 2. vyd. Praha: C. H. Beck, 2012, s. 116. ISBN 978-80-7400-428-5.

18 Ibid., s. 118.

19 Stanovisko trestního kolegia Nejvyššího soudu České republiky ze dne 30. ledna 2013, sp. zn. Tpjn $301 / 2012$.

20 Nález Ústavního soudu ze dne 12. října 2006, sp. zn. I. ÚS 69/06.

21 Nález Ústavního soudu ze dne 29. dubna 2014, sp. zn. I. ÚS 3113/13.

22 Usnesení Městského soudu v Praze ze dne 21. 9. 2011, sp. zn. 7 To 251/2011. 
prostředkem, jenž má smysl pouze $\mathrm{v}$ závažnějších případech protispolečenských jednání. Jestliže je dostačující uplatnění jiné než trestní odpovědnosti, tedy není-li ve smyslu principu trestní represe jako ultima ratio na místě vyvodit trestní odpovědnost, pak vyvození trestní odpovědnosti nemůže založit ani naplnění formálních znaků skutkové podstaty určitého trestného činu. Nevykazuje-li tedy určitý čin potřebnou škodlivost, nelze z jeho spáchání vyvozovat trestní odpovědnost, i když naplňuje všechny formálnî znaky skutkové podstaty určitého trestného činu. Podmínka společenské škodlivosti pak představuje tzv. materiální korektiv ve vztahu k formálním znakům skutkové podstaty trestného činu.

Dalším ustanovením, kde zákonodárce nechal prostor orgánu aplikujícímu právo, aby učinil úvahu podle okolností konkrétního případu, je v trestním právu ustanovení týkající se ukládání trestů. Podle \39 odst. 1 TZ při stanovení druhu trestu a jeho výměry soud príhlédne k povaze a závažnosti spáchaného trestného činu, k osobním, rodinným, majetkovým a jiným poměrům pachatele a k jeho dosavadnímu způsobu života a k možnosti jeho nápravy.

Při stanovení druhu trestu a jeho výměry dále soud přihlédne dle \39 odst. 3 TZ k polehčujícím a přitěžujícím okolnostem, přičemž zákonodárce u výčtu přitěžujících a polehčujících okolností užil demonstrativní výčet, z čehož vyplývá, že soud při rozhodování o druhu a výši trestu může prrihlédnout i k okolnostem v zákoně neuvedeným. Soud jako $\mathrm{k}$ polehčující okolnosti přihlédne mimo jiné $\mathrm{k}$ tomu, že pachatel spáchal trestný čin pod vlivem tíživých osobních nebo rodinných poměrů, které si sám nezpůsobil (\ 41 písm. e) TZ), nebo ke skutečnosti, že pachatel trestného činu upřímně litoval (\$ 41 písm. n) TZ). Upřímná lítost je lítostí, jež je vážně míněná a zároveň představuje vlastní postoj pachatele. ${ }^{23}$

Soud jako k prritěžující okolnosti přihlédne zejména k tomu, že pachatel spáchal trestný čin ze ziskuchtivosti, z pomsty, z národnostní, rasové, etnické, náboženské, třídní či jiné podobné nenávisti nebo z jiné zvlášt’ zavrženíhodné pohnutky ( 42 písm. b) TZ), spáchal trestný čin surovým nebo trýznivým způsobem, zákeřně, se zvláštní lstí nebo jiným obdobným způsobem (〔 42 písm. c) TZ).

Dalším institutem, $\mathrm{v}$ rámci něhož soud přihlíží ke konkrétním okolnostem, je upuštění od potrestání upravené v \46 TZ. Od potrestání pachatele, který spáchal př̀č́in, jeho spáchání lituje a projevuje účinnou snahu po nápravě, lze upustit, jestliže vzhledem $\mathrm{k}$ povaze a závažnosti spáchaného přcecinu a k dosavadnímu životu pachatele lze důvodně očekávat, že již pouhé projednání věci postačí k jeho nápravě i k ochraně společnosti. U upuštění od potrestání se jedná o výraz zásady humanity a pomocné úlohy trestní represe. ${ }^{24}$ Soud má možnost o upuštění od potrestání rozhodnout, pokud zjistí,

23 ŠÁMAL, op. cit., s. 552.

24 Ibid., s. 634. 
že v konkrétním př́padě existují individuální okolnosti na straně pachatele trestného činu, které zákon vymezuje pouze obecným způsobem.

Konkrétní okolnosti prrípadu hrají roli v posouzení státního zástupce zastavit trestní stíhání obviněného podle \ 172 odst. 2 zákona č. 141/1961, trestní řád (dále jen: „TŘ). Jedním z fakultativních důvodů uvedených $\mathrm{v}$ tomto ustanovení pod písmenem c) je i zastavení trestního stíhání, jestliže vzhledem k významu a míře porušení nebo ohrožení chráněného zájmu, který byl dotčen, zpưsobu provedení činu a jeho následku, nebo okolnostem, za nichž byl čin spáchán, a vzhledem k chování obviněného po spáchání činu, zejména $\mathrm{k}$ jeho snaze nahradit škodu nebo odstranit jiné škodlivé následky činu, je zřejmé, že účelu trestního řízení bylo dosaženo. V tomto prrípadě se plně uplatňuje diskreční pravomoc státního zástupce.

V př́padě použití algoritmu soudce nerozhoduje na základě okolností konkrétního případu, nýbrž na základě profilování, které pracuje s biometrickými údaji a dalšími daty a informacemi platnými v době tvorby algoritmu. Algoritmus pracuje se souborem znaků charakterizujících pachatele a jeho chování, které byly získané v minulosti, a činí z nich závěry o osobě pachatele v době rozhodování. Ačkoliv v době tvorby softwaru pro hodnocení rizikovosti obviněného mohla být souvislost mezi vysokým nebo naopak nízkým stupněm rizika platná, v době rozhodování již tato souvislost ve skutečnosti existovat nemusí.

Soudci se při použití algoritmického rozhodování stávají osobami, které algoritmem generované rozhodnutí podepisují, ne těmi, kteří v procesu aplikace práva interpretují právní normu na základě konkrétních okolností př́padu. Formálně by tedy náležela pravomoc vést proces a rozhodovat soudcům, ve skutečnosti by ,jejich“ rozhodnutí bylo závislé na výstupu algoritmu. Pokud by se soudci tímto výstupem neřídili a v takovém případě by nesli odpovědnost za své rozhodnutí, mohla by tato odpovědnost vyvolat u soudců tzv. odrazující účinek (chilling effect) v neprospěch vlastního úsudku.

Soudce by měl také hodnotit každého obviněného podle jeho individuálních charakteristik a jednotlivým charakteristikám obviněného přikládat pro zhodnocení rizika recidivy různou váhu. Tak např́klad podobné sociální postavení může být $\mathrm{v}$ jednom př́padě podstatné při posouzení obviněného jako rizikového $z$ hlediska recidivy, $v$ jiném případě může být sociální postavení pro riziko recidivy bez významu. Jak uvádí Antoinette Rouvroy, k rozhodování soudce patří i soucit, případně rozhořčení, které nelze transformovat do digitální podoby. Soucit nebo rozhořčení nejsou u algoritmického rozhodování prrítomny. ${ }^{25}$

25 ROUVROY, Antoinette a Bernard STIEGLER. Le régime de vérité numérique. De la gouvernementalité algorithmique à un nouvel État de droit. Scio [online]. 2015, roč. 4, s. 119 [cit. 30. 4. 2016]. Dostupné z: https://pure.fundp.ac.be/ws/files/13160335/socio_1251_4_le_regime_de_verite_numerique.pdf 
Algoritmy, které používají softwary na hodnocení rizikovosti, nemusí pracovat jen s předem určenými hodnotami. Použité algoritmy mohou mít podobu algoritmů s funkcí učení, které si skutečnosti relevantní pro výsledek volí podle předešlých zkušeností. Některé vstupní hodnoty může takový algoritmus začít akcentovat, jiné naopak při generování výsledku nezohlednit, přestože by v konkrétním př́padě mohly mít takové hodnoty pro rozhodnutí význam. Jiné hodnoty může algoritmus naopak mezi vstupní hodnoty přidat, pokud z jeho předchozí zkušenosti vyplyne vztah mezi nimi a rizikovostí obviněného. Tento vztah však nemusí být na úrovni indukce, ale na úrovni korelace neimplikující kauzalitu. To znamená, že výskyt určitých charakteristik u pachatelů, kteří se v minulosti dopustili recidivy, neznamená, že u všech pachatelů s touto charakteristikou bude riziko recidivy zvýšené.

Skutečnost, že je rozhodováno na základě algoritmu, bývá osobám, o nichž se rozhoduje, skryto, nebo tyto osoby neznají hodnoty, podle kterých algoritmus generuje výsledek. Při tomto druhu rozhodování je velkým problémem transparentnost neboli vědomost o tom, jakým způsobem se k rozhodnutí dospělo. ${ }^{26} \mathrm{Ti}$, o nichž je rozhodováno, nemají o algoritmickém rozhodování povědomí, a nemohou se proti němu tudíz bránit. Osoby jsou kategorizovány algoritmy, o kterých nejenže tito nemají žádné povědomí, ale ani nevědí, že mohou být algoritmy posuzovány a jakým způsobem.

Transparentní není algoritmické rozhodování jen ve vztahu k osobám, o kterých se rozhoduje. Ani ti, kteří algoritmu k rozhodování užívají, mnohdy nevědí, na základě jakých procesů a hodnot je algoritmem rozhodováno. To platí zejména pro algoritmy s funkcí učení, které se v čase mění. Důsledkem automatizace rozhodování je ztráta povědomí uživatelů o procesech, které jsou předmětem automatizace. Uživatelé si nejen neuvědomují, jak automatizované procesy fungují, ale ani nepostřehnou, že automatizovaný proces doznal vady a je tudíž nesprávný. Nerozpoznání nesprávnosti je zapříčiněno i tím, že uživatelé algoritmickému rozhodování důvěřují. "Jejich víra v software je natolik silná, že neberou v úvabu jiné zdroje informací, věetnè vlastnich pocitü. “27

V ř́zeních, kde by bylo algoritmické rozhodování pouze doporučené, nikoliv povinné, by mohlo nastat, že pokud by se uživatel rozhodl nerespektovat výsledek generovaný algoritmem, mohl by být uznán odpovědným za př́padné následky, které by při nerespektování výsledku nastaly. Jestliže by v prrípadě jiných, byt' i těžších následků, jež by byly důsledkem rozhodování algoritmu, odpovědnost uživatele nenastala, nelze se domnívat, že by uživatelé jiné informace nebo dokonce vlastní pocity při rozhodování zohlednili.

26 HANNAH-MOFFAT, Kelly. Actuarial Sentencing: An "Unsettled” Proposition. Justice Quarterly, 2013, roč. 30, č. 2, s. 284; nebo BRUNTON, Finn a Helen NISSENBAUM. Vernacular resistance to data collection and analysis: A political theory of obfuscation. First Monday [online]. 2011, roč. 16, č. 5. Dostupné z: http:// firstmonday.org/article/view/3493/2955

27 STEINER, op. cit., s. 41. 


\subsection{Matematická spravedlnost}

Soudní rozhodování v trestním řízení na základě matematického modelu pro výpočet pravděpodobností, bývá nazýváno matematickou spravedlností (actuarial justice). Pro výpočet pravděpodobností se využívá právě algoritmů. ${ }^{28}$

$\mathrm{V}$ trestním řízení se matematická spravedlnost uplatňuje ve Spojených státech amerických při vyhodnocování rizika spojeného s obviněným či odsouzeným a možností recidivy trestné činnosti. Oddělení pro probační a předsoudní službu administrativního úseku soudů Spojených států sestavilo Federální posouzení rizika v době po odsouzení (Federal Post Conviction Risk. Assessment). ${ }^{29}$ Posouzení rizika zahrnuje údaje o trestní minulosti pachatele, jeho vzdělání a pracovních zkušenostech, sociálních vazbách, bydlení, nebo majetkových poměrech. ${ }^{30}$ Část samostatného posouzení pachatele jako součást Federální posouzení rizika v době po odsouzení je založena na Psychologickém inventáři stylů kriminálního uvažování (Psychological Inventory of Criminal Thinking Styles). Po zadání př́slušných hodnot do systému je uživateli systému předložen výstup generovaný algoritmem, ukazující kriminální uvažování hodnocené osoby.

Poté, co jsou všechny hodnoty zaneseny do systému, jsou výstupem výsledky, které uvádí kategorii rizika osoby, její kriminogenní potřeby, neboli rizikové faktory a reakční faktory. Celkové riziko je určeno součtem bodů a hodnocená osoba je kategorizována jako pachatel, u kterého je riziko nízké, nízké až střední, střední a vysoké.

Federální zhodnocení rizika se zabývá i tím, kdy se mohou uživatelé systému ve zhodnocení rizik spojených s konkrétním pachatelem od rizika určeného algoritmem odlišit a navržené riziko nerespektovat. Nerespektovat výsledek generovaný algoritmem lze pouze výjimečně, a to navíc jen v určitých kategoriích, jako jsou pachatelé sexuálních trestných činů, pachatelé, kteří opakovaně použili násilí, pachatelé se závažnou duševní nemocí, mladiství a pachatelé s rozsáhlou trestní minulostí. Od zhodnocení rizika generovaného algoritmem se lze odchýlit i z jiných důvodů. Toto odchýlení musí být odůvodněné a vyžaduje souhlas nadřízeného. ${ }^{31}$

Matematický model v trestním řízení se ve Spojených státech používá ve čtyřech fázích tohoto řízení.32 První fází je fáze před zahájením soudního řízení a řízení o možnosti nahradit vazbu kaucí. Nástrojem k vyhodnocení rizika může být v této fázi řízení Zhodnocení veřejné bezpečnosti (Public Safety Assessment-Court), vyvinutý Nadací Laury a Johna Arnoldových, podporující mimo jiné i výzkum na poli trestního rrízení. Tento nástroj,

28 STEINER, op. cit., s. 41.

29 Administrative Office of the United States Courts Office of Probation and Pretrial Services. An Overview of the Federal Post Conviction Risk Assessment, op. cit.

30 Ibid., s. 10.

31 Ibid., s. 13.

32 CHRISTIN, ROSENBLAT, BOYD, op. cit., s. 3. 
který je již používán ve třech státech a 29 jurisdikcích, vyhodnocuje rizikovost podle faktorů jako je věk, pohlaví, rodinná situace, trestní minulost, dostavování se k úkonům trestního řízení, apod. ${ }^{33}$

Druhou fází, kde se matematický model používá, je fáze ukládání trestů v trestním řízení. V americkém státě Pensylvánie se zhodnocení rizik spojených s pachatelem využívá již při uložení trestu v samotném odsuzujícím rozsudku. Státní komise pro ukládání trestů navrhuje ukládání trestů tak, že pachatelům, u kterých systém vyhodnotí nízké riziko recidivy, by byl uložen kratší trest odnětí svobody, či by jim nebyl trest odnětí svobody uložen vůbec. Naproti tomu pachatelům, kteři by byli považováni za vysoce rizikové z hlediska recidivy, by byl uložen trest odnětí svobody delšího trvání. ${ }^{34}$

Další fází, kde matematické modely nacházejí uplatnění, je podmíněné odsouzení a podmíněné propuštění z výkonu trestu odnětí svobody. Pro posouzení rizika by mohlo být použito výše zmiňované Federální posouzení rizika v době po odsouzení.

Matematické modely se používají rovněž v soudnictví ve věcech mládeže. Při posouzení rizik vývoje kriminálního chování u mladistvých se užívá např. Nástroj zhodnocení rizik (Risk. Assessmnet Instruments) ${ }^{35}$ či nástroj vyvinutý společností Algorhythm, aplikovaný při posouzení rizikovosti recidivy u mladistvých pachatelů ve státě Florida. ${ }^{36}$

Matematické modely pro zhodnocení rizikovosti pachatelů se používají i v Evropě, např. v Belgii, Francii nebo v Nizozemí. ${ }^{37} \mathrm{~V}$ Nizozemí jsou matematické modely povinné při hodnocení rizika recidivy u mladistvých pachatelů ${ }^{38}$ a u pachatelů závažných trestných činů, kteří trestný čin spáchali v duševní poruše (tzv. tbs-gestelde).$^{39} \mathrm{~V}$ České republice není algoritmické rozhodování v trestním řízení využíváno a mezi českými soudci není podle zjišt'ování autorky o algoritmickém rozhodování nic známo.

33 Public Safety Assessment: A risk tool that promotes safety, equity, and justice. Laura and John Arnold Fundation [online]. Publikováno 14. srpna 2017 [cit. 25. 6. 2018]. Dostupné z: http://www.arnoldfoundation.org/ public-safety-assessment-risk-tool-promotes-safety-equity-justice/

34 BARRY-JESTER, Anna Maria, Ben CASSELMAN a Dana GOLDSTEIN. Should Prison Sentences Be Based On Crimes That Haven't Been Committed Yet? Fivethirtyeight.com [online]. Publikováno 4. 8. 2015 [cit. 14. 5. 2016]. Dostupné z: http:/ / fivethirtyeight.com/features/prison-reform-risk-assessment

35 BAIRD, Chris. A Comparison of Risk. Assessment Instruments in Juvenile Justice [online]. 2013 [cit. 14. 5. 2016]. Dostupné z: https://www.ncjrs.gov/pdffiles1/ojjdp/grants/244477.pdf

36 KATHLEEN, Hickey. Florida takes aim at juvenile recidivism with predictive analytics. GCN [online]. Publikováno 31. července 2015 [cit. 14. 5. 2016]. Dostupné z: https://gcn.com/articles/2015/07/31/ juvenile-predictive-analytics.aspx

37 MARY, Philippe. Pénalité et gestion des risques:versune justice « actuarielle » en Europe? Déviance et Société [online]. 2001, roč. 25, č. 1, s. 44 [cit. 14. 5. 2016]. Dostupné z: https://www.cairn.info/revue-deviance-et-societe-2001-1-page-33.htm

38 PLAISIER, Janine a Jenneke VAN DITZHUIJZEN. Risico taxatie bij verlof van gedetineerden. Een (inter) nationale vergelijking van instrumenten en procedures [online]. Amsterdam: Impact R \& D, 2008, s. 50 [cit. 14. 5. 2016]. ISBN 978-90-79262-02-1. Dostupné z: http://mpct.eu/wp-content/uploads/downloads/2013/03/Risicotaxatie-Verlof-Gedetineerden-1556_volledige_tekst_tcm44-167941-1.pdf

39 Ibid., s. 56. 


\subsection{Kritika matematické spravedlnosti}

Sonja Starr, odpůrkyně matematické metody zhodnocení rizikovosti pachatelů s ohledem na jejich možnou budoucí recidivu, připouští, že soudci vždy zvažovali budoucí riziko recidivy pachatele. Dělo se tak ovšem pouze neformálně, bez konkrétních hodnot, jež museli soudci vzít při rozhodování v úvahu. V tom smyslu mohou být matematické metody ve svých předpovědích přesnější. Problémem podle Starr není zhodnocení rizika recidivy jako takové. Zhodnocení rizika recidivy je založeno na demografických a sociálně ekonomických faktorech, tedy na faktorech, které nemůže pachatel ovlivnit. Starr navrhuje, aby místo výše uvedených kritérií pro zhodnocení rizika recidivy byly brány v úvahu faktory, na něž pachatel měl vliv nebo je může v budoucnu ovlivnit, mimo jiné jeho minulé chování a chování v době rozhodování soudu. ${ }^{40}$

Na konci dvacátého století Jonathan Simon a Malcolm Feeley upozorňovali na změnu v př́stupu k ukládání trestů a vnímání účelu trestu. Ústředním prvkem nového diskursu je podle Simona a Feeleyho nahrazení posuzování pachatelů na základě jejich morálních vlastností individuálně zjišs'ovaných u každého z nich matematickým jazykem, spočívajícím na výpočtech pravděpodobností a na statistických prvcích a vzorcích odvozených od chování jiných pachatelů, nikoliv těch, proti nimž se řízení vede. ${ }^{41}$ „Nová penologie není o trestáni ani resocializaci jednotlivcui. Je o identifikaci a ř́zení neprizpiosobivých skupin. Je svou racionalitou zamèrena nikoliv na individuální chováni nebo dokonce organizaci spolě̌enství, ale na manažerskyich procesech. Jejím cílem neni odstranit trestnou cinnost, ale to, aby toto bylo tolerováno prostrednictvím systémové koordinace. “42

Podle Bernarda Harcourta „matematické metody použivaji v trestnim právu statistické predpovédi o kriminalité skupin nebo skupinových charakteristik k tomu, aby uríly výsledky trestníbo rízení pro konkrétni jednotlivce náležici do téchto skupiny. “"43 Používání matematických modelů při ukládání trestů nebo $\mathrm{v}$ rámci rozhodování o podmínečném propuštění se zaměruje na předvídání budoucího možného kriminálního chování, na základě kterého je pak uložen trest v určité délce, či je rozhodnuto o podmínečném propuštění, resp. o setrvání ve výkonu trestu odnětí svobody. ${ }^{44}$ Harcourt matematické metody v této oblasti soudního rozhodování podrobuje kritice. Spravedlivé ukládání trestů nemůže být podle Harcourta založeno na riziku, že se dotyčný pachatel bude dopouštět trestné činnosti někdy

40 STARR, Sonja. Sentencing, by the Numbers. The New York Times [online]. Publikováno dne 10. srpna 2014 [cit. 31. 5. 2016]. Dostupné z: http://repository.law.umich.edu/law_econ_current/90

41 SIMON, Jonathan a Malcolm FEELEY. The New Penology: Notes on the Emerging Strategy of Corrections and Its Implications. Criminology [online]. 1992, Vol. 30, no. 4, s. 452 [cit. 31. 5. 2016]. Dostupné z: http:/ / scholarship.law.berkeley.edu/cgi/viewcontent.cgi?article $=1717$ \& context $=$ facpubs

42 Ibid., s. 455.

43 HARCOURT, Bernard. Against Prediction. Profiling, Policing, and Punishing in an Actuarial Age. Chicago: The University of Chicago Press, 2007, s. 17. ISBN 978-0-226-31614-7.

44 Ibid., s. 25. 
v budoucnu. ${ }^{45}$ Matematické metody jsou založeny na profilování skupin. Pokud soudci tyto metody používají, získají dojem, že je oprávněné trestat určitým způsobem nebo délkou trestu odnětí svobody členy určité skupiny, protože právě členové této skupiny se dopouštějí trestné činnosti častěji než členové jiné skupiny. Legitimnost uloženého trestu se nebude odvijet od charakteru spáchaného trestného činu, nýbrž od možné budoucí trestné činnosti, jež bude předpovězena algoritmem na základě profilu člena určité skupiny. ${ }^{46}$

Proti matematickým metodám a přístupům založený na statistice $\mathrm{v}$ trestním řízení se v sedmdesátých letech dvacátého století stavěla i Barbara Underwood. Podle ní postrádají statistické metody flexibilitu a posouzení individuálních charakteristik trestního činu. Tyto metody naopak zdůrazňují obecná pravidla, jednoznačně daná kritéria pro rozhodnutí a nižší administrativní náklady. ${ }^{47}$

Podle Harcourta utváří matematické metody sociální realitu zdůrazňováním korelace mezi charakteristikami určité skupiny a kriminalitou. Pachatel, jenž v modelu vykazuje vyšší riziko recidivy, je stigmatizován profilem, který ho kategorizuje jako člena skupiny a tudíž mu přičítá i budoucí kriminální chování. $V$ důsledku toho má tento pachatel obtížnější postavení při návratu do běžného života, což má za následek právě větší pravděpodobnost recidivy. ${ }^{48}$ Výše popsaný začarovaný kruh není výsledkem používání matematických metod v trestním řízení. Matematické metody používané orgány činnými v trestním řízení tento př́stup posvěcují, činí z něho oficiální součást trestní politiky. Nadto, odchýlení se od výsledku generovaného algoritmem je podmiňováno splněním dodatečných kritérií. Tyto aspekty používání matematických metod v trestním rúzení jsou v rozporu se zásadou zákazu diskriminace a právem na spravedlivý proces. Nebezpečí diskriminace je rovněž spojeno se zpracováním biometrických osobních údajů druhé generace. Nesprávná kategorizace jednotlivce do určitého behaviorálního biometrického profilu na základě jeho skutečných či domnělých psychologických rysů může vyústit v jeho budoucí diskriminaci. ${ }^{49} \mathrm{~V}$ rozporu se zásadou zákazu diskriminace je, pokud je s obviněnými nebo odsouzenými v trestním rrízení zacházeno jinak z důvodu jejich rasy, př́islušnosti k etnické skupině, pohlaví nebo sociálního postavení. V současnosti používané systémy pro zhodnocení rizikovosti recidivy pachatele sice neobsahují biometrický údaje o rase jako jednu

45 HARCOURT, Bernard. Against Prediction. Profiling, Policing, and Punishing in an Actuarial Age. Chicago: The University of Chicago Press, 2007, s. 32. ISBN 978-0-226-31614-7.

46 Ibid., s. 33.

47 UNDERWOOD, Barbara. Law and the Crystal Ball: Predicting Behavior with Statistical Inference and Individualized Judgment. Yale Law Journal [online]. 1979, roč. 88, s. 1425 [cit. 31. 5. 2016]. Dostupné z: http:/ / digitalcommons.law.yale.edu/cgi/viewcontent.cgi?article $=4140 \&$ context $=$ fss_papers

48 Ibid., s. 36.

49 GÜTTLER, Vojen a Ján MATEJKA. K otázkám některých základních lidských práv a svobod v souvislosti s právní ochranou biometrických údajů. Právník, Praha: Ústav státu a práva AV ČR, v. v. i., 2016, č. 12 , s. 1038. 
ze zadávaných hodnot, nicméně do systému jsou zadávány takové hodnoty, ze kterých se rasa nebo etnická příslušnost dá odvodit. Takovou hodnotou je např. bydliště, nebot' určité oblasti bývají obývány př́islušníky sociální skupiny s nízkými příjmy, nebo příslušníky etnické či národnostní menšiny. Některé systémy pak explicitně pracují s pohlavím pachatele jako s hodnotou ovlivňující riziko recidivy. ${ }^{50}$

K rovnosti před zákonem ve spojení s právem na spravedlivý proces se vyjádřil Nejvyšší soud Spojených států ve svém rozsudku Griffin v. Illinois. ${ }^{51}$ Podle tohoto soudu je zajištění rovnosti ve výkonu spravedlnosti pro osoby chudé a bohaté nebo pro ty mocné a osoby bez vlivu velmi starý problém, nicméně se v tuto spravedlnost lidé stále doufají a snaží se k tomuto cíli prriblížit. Zajištění rovnosti před spravedlností v trestním řízení je garantováno ústavou zaručeným právem na spravedlivý proces a zákazem diskriminace. Nejvyšší soud Spojených států v tomto rozsudku rovněž uvádí, že to, aby si byly osoby obžalované ze spáchání trestného činu před soudem rovny co do podmínek daných zákonem, je jedna z hlavních zásad celého soudního systému.

V dalším rozsudku United States v. Virginia Nejvyšší soud Spojených států odmítl rozdílné zacházení na základě pohlaví, které je důsledkem zobecňování charakteristik, které se všeobecně jednomu nebo druhému pohlaví přičítají. Princip rovného zacházení s muži a ženami obsahuje mimo jiné záruky před přilišným zobecňováním, nebot' rozsudky, které by byly na takovém zobecňování založeny, by udržovaly historické vzorce diskriminace na základě pohlaví. ${ }^{52}$

Důvodem pro odmítnutí trestu s podmíněným odkladem nemůže podle Nejvyššího soudu Spojených států ani špatná majetková situace odsouzeného. Stát nemůže ospravedlnit uložení výkonu trestu odnětí svobody podmínečné odsouzenému, který prokázal dobrou víru a snažil se splatit svůj dluh vưči společnosti. Nelze, aby stát označil takového jednotlivce za chudého a klasifikoval ho na základě jeho chudoby jako nebezpečného. Tato praxe by ve svém důsledku znamenala, že takové osoba bude potrestána pro svou chudobu, což je podle Nejvyššího soudu Spojených států nepř́ípustné. ${ }^{53}$

Nejvyšší soud Spojených států odmítá ve své judikatuře i rozdílné zacházení založené na statistice a naopak akcentuje jedinečnost a individuální př́stup. ${ }^{54}$ Starr poukazuje

50 CHRISTIN, Angèle, Alex ROSENBLAT a Danah BOYD. Courts and Predictive Algorithms [online]. 2015, s. 5 [cit. 31. 5. 2016]. Dostupné z: http://www.law.nyu.edu/sites/default/files/upload_documents/ Angele\%20Christin.pdf

51 Rozsudek Nejvyššího soudu Spojených států ze dne 23. dubna 1956 Griffin v. Illinois, 351 U.S. 12 (1956).

52 Rozsudek Nejvyššího soudu Spojených států ze dne 26. června 1996 United States v. Virginia, 518 U.S. 515 (1996).

53 Rozsudek Nejvyššího soudu Spojených států ze dne 24. května 1983 Bearden v. Georgia, 461 U.S. 660 (1983).

54 STARR, Sonja. Evidence-Based Sentencing and the Scientific Rationalization of Discrimination. Law \& Economics Working Papers [online]. 2013, s. 16 [cit. 31. 5. 2016]. Dostupné z: http:/ / repository.law. umich.edu/law_econ_current/90 
na to, že neexistuje žádný relevantní výzkum, podle něhož by matematické zhodnocení rizika budoucí recidivy znamenalo lepší výsledky v předvídání recidivy pachatele než individuální posouzení každého případu. ${ }^{55} \mathrm{Na}$ absenci rozdílů mezi algoritmickou a lidskou predikcí poukazuje i nedávná studie Julia Dressel and Hany Farid. Úspěšnost predikce recidivy byla u algoritmického i u lidského posouzení v průměru 65\% ${ }^{56}$

Porušení práva na spravedlivý proces je možné spatřovat i v tom, že obvinění nemusí mít vůbec povědomí o tom, že o délce jejich trestu nebo o zamítnutí podmínečného propuštění bylo rozhodnuto nikoliv na základě jejich individuálních charakteristik, ale na základě matematického modelu, který pracuje s hodnotami platnými pro skupinu, jejímž př́slušníkem dotyčný obviněný je nebo se zdá být. ${ }^{57}$

Používání matematického modelu pro rozhodování pachatelů ohledně jejich budoucí recidivy, které je založeno na sociálně kulturních, demografických a ekonomických faktorech určité skupiny, jejímž je pachatel př́islušníkem, jsou v rozporu s judikaturou Nejvyššího soudu Spojených států, který akcentuje individualitu pachatele nebo jiné osoby, o které je rozhodováno $\mathrm{v}$ jiném než trestním řízení, a oproštění se od nepodložených zobecňování založených na předpojatosti společnosti k jednotlivci pouze pro prŕíslušnost ke skupině, o níž má společnost své, mnohdy fakty nepodložené, představy.

Výzkum mezi soudci používajícími pro své rozhodování systémy pro zhodnocení rizika pachatele na základě matematické metody ukázal, že ani profesionálové nechápou podstatu této metody. „Přstǒ̌e jsou vyškoleni v použiváni a interpretaci nástroju pro hodnoceni rizik, zápasi osoby praktikujici právo s významem hodnoceni pravdèpodobnosti a relativníbo významu položele obsažených v nástrojich pro z̧hodnoceni rizi ikovosti. Misto toho, aby pochopily, že jedinec s vysokým skóre rizika sdili charakteristiky s celou skupinou vysoce rizikových pachateli, osoby praktikujici právo budou pravdèpodobnè vnimat tohoto jedince jako vysoce rizikovébo pachatele. Praktické bledisko korelace se stává prírinnou souvislosti a potenciálni riziko je preloženo jako administrativni jistota. Pri použiti ve fázi rízeni pred vynesením rozsudku mohou soudy predpokládat, že pachatel s, vysokým rizikem 'predstavuje vètši nebezpeč pro společnost a podle toho jemu nebo ji také ulo ži trest. Rizilkové skóre ovšem pouze identifikuje (v rámci żjevných limitü), u koho je vètš pravdèpodobnost, že se zunovu dopusti trestného činu, a v přphadě dynamických nástroju identifikuje potreby, kterými jsou cíle zacházeni v nápravných programech, které by mohly sniěrit pravděpodobnost recidivy. “58

55 STARR, Sonja. Evidence-Based Sentencing and the Scientific Rationalization of Discrimination. Law \& Economics Working Papers [online]. 2013, s. 36 [cit. 31. 5. 2016]. Dostupné z: http://repository.law. umich.edu/law_econ_current/90

56 DRESSEL, Julia a Hany FARID. The accuracy, fairness, and limits of predicting recidivism. Science Advances [online]. 2018, roč. 4, č. 1, s. 3 [cit. 27. 1. 2018]. Dostupné z: http://advances.sciencemag.org/ content/4/1/eaao5580/tab-pdf

57 Ibid., s. 47.

58 HANNAH-MOFFAT, op. cit., s. 278. 
Hannah-Moffat ve svém výzkumu dokládá, že určité charakteristiky, které jsou presumované u skupiny osob, považují ti, kteří by měli být nezávislí a nestranní, za charakteristiky jednotlivce, prríslušníka této skupiny, a tudíž mu připisují rysy celé skupiny. Př́slušnost ke skupině je rozhodující faktor pro uložení trestu.

Pokud se soudci a státní zástupci odchýlí od zhodnocení rizika generovaného algoritmem, musí svoje odchylné rozhodnutí zvláště odůvodnit s ohledem na důvody tohoto rozhodnutí. Při vyplňování hodnot do příslušného formuláře proto někteří vyplní takovou hodnotu, aby získali požadovaný výsledek bez nutnosti obsáhlého odůvodnění a odpovědnosti za nerespektování výsledku systému pro zhodnocení rizik. ${ }^{59}$ Důsledkem může být, že algoritmus se schopností učit se bude i těm profesionálním uživatelům, kteř́ hodnoty nemění, generovat výsledky, které nejenže neodpovídají konkrétnímu jednotlivci, ale ani charakteristikám dané skupiny. Výsledkem může být, že jednotlivec bude vyhodnocen jako rizikový, přestože tomu tak není jak na základě jeho osobních charakteristik, tak i charakteristik skupiny, jejímž je př́slušníkem.

Výstupem matematických modelů hodnocení rizika nemusí být správný výsledek rizikovosti pachatele z hlediska jeho budoucí recidivy. Chyby modelů jsou dvojího druhu. Může se jednat o falešně pozitivní výsledek, kdy se předpokládaná událost nedostaví. Pachatel je kupř́íkladu označen jako jedinec s vysokým rizikem recidivy, ale v budoucnu žádný trestný čin nespáchá. Výsledek může být i falešně negativní. Falešně negativním výsledkem je situace, kdy model chybně předpokládá, že určitá událost nenastane. Pachatel je např. nesprávně označen jako osoba, u níž je riziko recidivy nízké, přestože se v určité době trestného činu opět dopustí. ${ }^{60}$ Chris Baird ve svém výzkumu prověřoval, zda se pachatelé, u nichž bylo riziko recidivy vyhodnoceno matematickým modelem, skutečně chovají tak, jak model předpověděl. Za časovou hranici byly zvoleny dva roky po prvním hodnocení. Baird zjistil, že z celkového počtu 119935 př́padů matematický model používaný v americkém městě Filadelfie označil 18812 pachatelů jako vysoce rizikových z hlediska recidivy. Model tedy označil 15,7 \% pachatelů jako rizikové. V dvouletém horizontu se ukázalo, že z 18812 pachatelů, kteří byli zhodnoceni jako rizikoví, se dopustilo další trestné činnosti 7112 pachatelů, zatímco u 11700 pachatelů se tato predikace ukázala jako chybná. ${ }^{61}$

Rizikovost pachatele s ohledem na možnost recidivy by měla být v individuálním případě předmětem dokazování. V českém právním řádu i v právních řádech států kontinentální Evropy platí zásada volného hodnocení důkazů spolu s požadavkem na vnitřní

59 HANNAH-MOFFAT, op. cit., s. 285.

60 BARNES, Geoffrey C. a Jordan M. HYATT. Classifying Adult Probationers by Forecasting Future Offending [online]. 2012, s. 21 [cit. 14. 5. 2016]. Dostupné z: https://www.ncjrs.gov/pdffiles1/nij/grants/238082. pdf

61 Ibid., s. 22. 
přesvědčení soudce. $^{62}$ Tato zásada je vyjádřena v $\int 2$ odst. 6 Tř. Podle tohoto ustanovení hodnotí orgány činné $\mathrm{v}$ trestním řízení důkazy podle svého vnitřního přesvědčení založeného na pečlivém uvážení všech okolností případu jednotlivě i v jejich souhrnu. Zásada volného hodnocení důkazů znamená, že orgán činný v trestním řízení nejen může, ale dokonce musí přihlédnout k okolnostem konkrétního př́padu, k jeho zvláštnostem a charakteristickým rysům. Volné hodnocení důkazů má za cíl zabránit mechanickému postupu při hodnocení důkazů. ${ }^{63} \mathrm{I}$ když je soudce nebo jiný orgán činný v trestním řízení povinen $\mathrm{v}$ odůvodnění svého rozhodnutí důkazy vyčerpávajícím způsobem popsat a logicky i věcně přesvědčivým způsobem odůvodnit, ${ }^{64}$ nepřisuzuje zákon žádnému důkazu zvláštní význam a váhu. Soudce tak hodnotí důkazy na základě svého vnitřního přesvědčení v každém individuálním případě. Pokud by byl soudce při hodnocení důkazů vázán výsledkem generovaným algoritmem, došlo by k porušení výše uvedené zásady. Vnitřní přesvědčení soudce by bylo, i v př́ípadě, že by byl generovaný výsledek pouze doporučující, s vysokou pravděpodobností ovlivněno i s ohledem na výše zmíněnou presumovanou objektivitu algoritmického rozhodování. Zavedení algoritmického rozhodování v trestním řízení by bylo v rozporu s výše uvedenými zásadami a zaznamenalo by tak odklon od moderních principů kontinentálního trestního řízení.

\section{Problém algoritmického rozhodování $\mathrm{v}$ trestním řízení a základní lidská práva ve světle evropské judikatury}

\subsection{Zákaz diskriminace}

Přestože by rozhodování na základě algoritmu mělo být objektivní, to znamená nejen nezávislé a nestranné, ale rovněž prosté jakéhokoliv nelegitimního rozlišování osob a diskriminace, vyvstává při použití algoritmu k rozhodování obava z různého zacházení s osobami na základě jejich skutečného nebo domnělého atributu. Tímto atributem může být národnost, etnická příslušnost, příslušnost k určité sociální skupině, pohlaví, věk či jakýkoliv jiný znak. Podle Christophera Slobogina jsou atributy, jako je pohlaví nebo věk, součástí metodologie pro predikci trestné činnosti. ${ }^{65} \mathrm{Jak}$ jsme již výše uvedli, do hodnot, se kterými algoritmus pracuje, mohou být zařazeny i jiné znaky, např. rasa, etnická prŕíslušnost nebo prŕíslušnost k sociální skupině.

62 Např. čl. 427 francouzského trestního řádu (Code de procédure pénal), či \ 261 německého trestního rádu (Strafprozeßordnung).

63 ŠÁMAL, Pavel a kol. Trestní rád. Komentár. 7. vyd. Praha: C. H. Beck, 2013. Dostupné z: Databáze Beck-online [online]. [cit. 17. 4. 2018].

64 Nález Ústavního soudu ze dne 24. listopadu 2005, sp. zn. I. ÚS 455/05.

65 SLOBOGIN, Christopher. Proving the Unprovable. The Role of Law, Science, and Speculation in Adjudicating Culpability and Dangerousness. Oxford: Oxford University Press, 2007, s. 112. ISBN 0-19-518995-7. 
Rozpor mezi objektivitou algoritmického rozhodování a obavou z odlišného zacházení a diskriminace vysvětluje Rouvroy vlastností algoritmu spočívajícím v učení se z předchozích operací. Algoritmus tak podle Rouvroy převezme pohled na svět svých uživatelů a použitím jím generovaných výsledků je ve správnosti svých výsledků dále utvrzován. Diskriminaci je velmi obtížné prokázat kvůli argumentu objektivity rozhodování na základě algoritmu. ${ }^{66}$

Rozhodování na základě hodnot jako jsou rasa, etnická příslušnost, věk, pohlaví nebo př́islušnost k sociální skupině může být do systému př́mo zaneseno. Algoritmus pak s těmito hodnotami pracuje od začátku. Výstupy na základě těchto hodnot může algoritmus začít generovat $\mathrm{v}$ průběhu fungování systému $\mathrm{v}$ důsledku učení z předchozích operací, pokud se uživatelé řídí výstupy generovanými na základě těchto hodnot.

Rozlišujeme dva druhy diskriminace, a to diskriminaci prrímou a diskriminaci nepřímou. Přímou diskriminací rozumíme jednání, kdy se s jednou osobou zachází méně příznivě než s jinou osobou ve srovnatelné situaci na základě nepř́ípustného kritéria. ${ }^{67}$ Nepř́má diskriminace vyvolává rozdílné zacházení v aplikační rovině, která je zapříčiněna diskriminační interpelací normy nebo její vadnou konstrukcí. ${ }^{68}$

Podstatu diskriminace ve svém odlišeném stanovisku k rozsudku Evropského soudu pro lidská práva (dále jen „ESLP“) Chassagnou a ostatni proti Francii ${ }^{69}$ výstižně shrnul soudce tohoto soudu Boštjan Zupančič. „JJ]e třeba samozřejmè chápat, že účel prakticky každé právni normy - at’ už se jedná o prǐkaz, zákaz č zmocnèni - je rozlišovat mezi různými kategoriemi (trídami) právnich subjektui. Dokonce i trestní zákony jsou v tomto smyslu ,diskriminačni“ mezi tèmi, k.teř̀ se nadále považuji za nevinné, a těmi, keteř byli shledáni vinnými. Každý právni systém funguje na principu koncepónich rozdílu s právnimi dìsledky - v ústavnim, občanském, trestnim, správnim, mezinárodnim aj. právu. Význam latinskébo slovesa „discriminare" je rozlisit, vnímat významné rozdíly atd. Nicméné i v běžném jazyce slovo „diskriminace" nabývá pejorativních konotací, pokud neexistuje rozumný divod pro rozdílné zacházeni s jednotlivci (nebo trídon jednotlivcui). Tam, kede takové rozdílné zacházení, plynouci z.predsudkư nebo z nedostatku racionálni úvahy, je spojeno s užitím moci, hovoríme o libovili, vrtošivosti, nekonzistentnosti, neregulérnosti, neprédvídatelnosti ... Intuitivnè chápeme, že tyto atributy jsou zucela neslučitelné s ideálem právního státu."

Evropská Úmluva o ochraně lidských práv a základních svobod (dále jen: „EÚLP“) diskriminaci při užívání práv a svobod garantovaných toto úmluvou zakazuje v čl. 14. Užívání práv a svobod musí být zajištěno bez diskriminace založené na jakémkoli důvodu,

66 ROUVROY, Antoinette. “Of Data and Men”.Fundamental Rights and Freedoms in a World of Big Data [online]. 2011, s. 33 [cit. 4. 5. 2016]. Dostupné z: http://works.bepress.com/antoinette_rouvroy/64

67 BOBEK, Michal, Pavla BOUČKOVÁ a Zdeněk KÜHN (eds.). Rovnost a diskriminace. Praha: C. H. Beck, 2007, s. 43. ISBN 80-903786-0-9.

68 Ibid., s. 53.

69 Rozsudek ESLP ze dne 29. dubna 1999, stíž. č. 25088/94, 28331/95 a 28443/95 ve věci Chassagnou a ostatni proti Francii. 
jako je pohlaví, rasa, barva pleti, jazyk, náboženství, politické nebo jiné smýšlení, národnostní nebo sociální původ, příslušnost k národnostní menšině, majetek, rod nebo jiné postavení. Toto ustanovení nestanoví, že by stát mohl toto právo nebýt diskriminován z legitimních důvodů omezit, tak jako je tomu např. v př́padě práva na ochranu soukromého a rodinného života nebo práva na svobodu projevu.

Podle čl. 1 odst. 1 Protokolu č. 12 k EÚLP užívání každého práva přiznaného zákonem musí být zajištěno bez jakékoli diskriminace z důvodu pohlaví, rasy, barvy pleti, jazyka a náboženství, politického či jiného smýšlení, národnostního či sociálního původu, př́islušnosti k národnostní menšině, majetku, rodu či jiného postavení. Druhý odstavec tohoto ustanovení stanoví, že nikdo nesmí být diskriminován žádným orgánem veřejné moci z jakéhokoli důvodu, zejména z důvodů uvedených v prvním odstavci.

Literatura rozděluje na základě judikatury ESLP tak zvaná a priori podezřelá kriteria a kritéria, která a priori podezřelá nejsou. ${ }^{70}$ Rozdíl mezi výše uvedenými kritérii je v míře uvážení ESLP. Zatímco u kritérií, která podezřelá nejsou, může stát uplatnit širší míru uvážení, u kritérií podezřelých je třeba, aby stát odůvodnil rozdílné zacházení objektivními a závažnými důvody, přičemž musí být zachována proporcionalita mezi užitými prostředky a požadovaným účelem rozdílného zacházení. ${ }^{71}$ A priori podezřelými důvody jsou pohlaví, sexuální orientace, národnost, rasa nebo etnický původ, manželský či nemanželský původ dítěte a zdravotní stav nebo postižení. ${ }^{72}$

Rozdílné zacházení v rúzení je podle ESLP diskriminací. Diskriminace vede k porušování práva na spravedlivý proces. V př́padě Paraskeva Todorova proti Bulharsk $u^{73}$ byla stěžovatelka romského původu odsouzena za podvod ke třem rokům odnětí svobody bez podmíněného odkladu výkonu trestu. V odůvodnění rozsudku byl zmíněn její romský původ, navíc soud prvního stupně ani odvolací soud neodůvodnily, proč podmíněný odklad výkonu trestu není možný. Soud prvního stupně nadto ve svém rozsudku uvedl, že př́slušníci menšin nepovažují podmíněný trest odnětí svobody za opravdové odsouzení. ESLP zopakoval, že čl. 14 zakazuje jakékoliv neodůvodněné rozdíly v užívání práv a svobod zaručených EÚLP na základě uvedených kritérií, které nejsou v tomto ustanovení uvedeny zcela vyčerpávajícím způsobem. ESLP uvedl, že pokud argument v rozsudku soudu zmiňuje rozdílné zacházení, které tento soud uplatňuje, a tento argument je založen výhradně na základě kritérií uvedených v čl. 14 ESLP, je stát povinen toto rozdílné zacházení v tomto rozsudku odůvodnit, což se ve výše uvedeném případě nestalo,

70 Srov. KABELOVÁ DOLEJŠOVÁ, Kristýna. Zákaz diskriminace jako právní problém v judikature Evropskébo soudu pro lidská práva. Praha: Univerzita Karlova v Praze, Právnická fakulta, 2012, s. 114. ISBN 978-80-87146-60-6.

71 Rozsudek ESLP ze dne 24. července 2003, stíž. č. 40016/98 ve věci Karner proti Rakousku.

72 Srov. WÁGNEROVÁ, Eliška a kol. Listina qákladnich práv a svobod. Komentár. Praha: Wolters Kluwer ČR, 2012, s. 104. ISBN 978-80-7357-750-6.

73 Rozsudek ESLP ze dne 25. března 2010, stíž. č. 37193/07 ve věci Paraskeva Todorova proti Bulharsku. 
když jediným tvrzeným důvodem byla etnická př́islušnost stěžovatelky. ESLP dospěl $\mathrm{k}$ tomu, že $\mathrm{v}$ uvedeném př́padě existoval neodůvodněný rozdíl v zacházení v neprospěch stěžovatelky v trestním řízení, z čehož vyplývá porušení čl. 14 EÚLP.

$\mathrm{V}$ prrípadě Fredin se ESLP zabýval důkazním břemenem na straně stěžovatele, který o sobě tvrdil, že je obětí diskriminace. Soud ve svém rozsudku Fredin proti Švédsken ${ }^{74}$ připomněl, že čl. 14 EÚLP garantuje ochranu proti diskriminaci, která spočívá v rozdílném zacházení s osobami ve srovnatelných situacích bez objektivního a rozumného zdůvodnění. Aby byla stížnost k ESLP týkající se porušení tohoto článku úspěšná, musí být založena mimo jiné na tvrzení, že situace údajné oběti diskriminace může být považována za podobnou situaci osob, s nimiž bylo zacházeno lépe.

Diskriminací nemusí být pouze odlišné zacházení. Diskriminací může být podle ESLP i stejné zacházení v př́padě, že postavení jednotlivce je fakticky odlišné od postavení jiných. Porušení čl. 14 EÚLP může být zapříčiněno stejným zacházením s osobami, které si nejsou fakticky rovné. Stejné zacházení faktickou nerovnost prohlubuje, místo aby ji korigovalo. Rozdílné zacházení je podle tohoto soudu diskriminační, pokud nemá objektivní a rozumné zdůvodnění, tedy pokud nesleduje legitimní cíl nebo pokud neexistuje proporcionalita mezi použitými prostředky a cílem, kterého má být dosaženo (Stec a dalši proti Spojenému královstvi). ${ }^{75}$ Ve prospěch rozdílného zacházení v prípadech faktické nerovnosti se ESLP vyjádřil i v rozsudku ve věci Thlimmenos proti Recku. ${ }^{76}$ Právo nebýt diskriminován při požívání práv zaručených ESLP je porušeno, když stát, aniž by sdělil objektivní a rozumné zdůvodnění, nezachází odlišně s osobami, jejichž situace se výrazně liší.

Obdobně zákaz diskriminace obsahuje i Listina základních lidských práv Evropské unie (dále jen: „Listina EU“). Podle čl. 21 Listiny EU se zakazuje jakákoli diskriminace založená zejména na pohlaví, rase, barvě pleti, etnickém nebo sociálním původu, genetických rysech, jazyku, náboženském vyznání nebo přesvědčení, politických názorech či jakýchkoli jiných názorech, př́slušnosti k národnostní menšině, majetku, narození, zdravotním postižení, věku nebo sexuální orientaci. Stejně jako EÚLP nezná ani Listina EU žádné legitimní omezení zákazu diskriminace.

Diskriminaci v požívání základních práv a svobod zakazuje i Listina. Podle čl. 3 odst. 1 se základní práva a svobody zaručují všem bez rozdílu pohlaví, rasy, barvy pleti, jazyka, víry a náboženství, politického či jiného smýšlení, národního nebo sociálního původu, př́slušnosti k národnostní nebo etnické menšině, majetku, rodu nebo jiného postavení.

74 Rozsudek Evropského soudu pro lidská práva ze dne 18. února 1991, stíž. č. 12033/86 ve věci Fredin proti Š́édsku.

75 Rozsudek ESLP zedne 12. dubna 2006, stíž. č. 65731/01 a č. 65900/01 ve věci Stec a dalšiproti Spojenému královstuí.

76 Rozsudek ESLP ze dne 6. dubna 2000, stíž. č. 34369/97 ve věci Thlimmenos proti Řecku. 
Podle nálezu Ústavního soudu může k zásahu do práva chráněného čl. 10 Listiny $^{77}$ dojít jednáním se zamýšlenými i nezamýšlenými důsledky, jakož i jednáním směřujícím proti obecně vymezené skupině osob, $\mathrm{k}$ níž se jednotlivec cítí být př́islušný. ${ }^{78}$ Ústavní soud kritizoval argumentaci obecných soudů, podle níž není možné, aby byla osobnost jednotlivce dotčena tím, že se diskriminační jednání vztahovalo na množinu vymezenou obecným rozsahem. Podle Ústavního soudu ,[z]de absentuje argumentace, rádné a présvědurivé zdìvodnèni takového názoru, a tudí̌ i porušeni práva na spravedlivý proces stěrovovatele. Takový deficit $v$ argumentaci plati o to vice, kdyžje již. z. povaby věci zrégmé, že pokud se určitý jednotlivec cití být

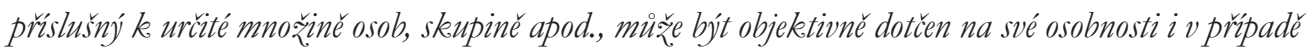
formulace vyslovené pouze smèrem ke množině osob (tj. bez individualizace osob). Je-li totiž výrok směrován proti množině osob (tj. vymezené obecnè), je z. povaby věci směrován i proti jednotlivcuim, nebot' ti, resp. pouze ti, jsou jejím vlastním obsahem (podmnožinami). Název takové množiny je jen prostredkem pro označení obsabu, který tvoř jednotlivci, tedy toliko formou, pričemž se jedná o obsah, nikoliv o formu. ${ }^{679}$

$\mathrm{V}$ případě algoritmického hodnocení rizikovosti pachatele trestného činu s ohledem na jeho budoucí recidivu se podle našeho názoru jedná o diskriminaci prímou, nebot' s pachatelem, který je určité rasy, etnicity, věku, pohlaví nebo který je př́íslušníkem určité sociální nebo sociálně kulturní skupiny, je zacházeno méně příznivě než s pachateli, kteřî tyto atributy nevykazují. Méně příznivým zacházením se zde rozumí vyhodnocení pachatele jako rizikovějšího ve srovnání s jinými pachateli pouze z výše uvedených důvodů. Méně prríznivým zacházením bude $\mathrm{v}$ př́padě tohoto typu algoritmického rozhodování př́snější druh trestu, napr. uložení trestu výkonu odnětí svobody takovému pachateli, zatímco jinému pachateli bude uložen trest nespojený s omezením na svobodě, uložení nepodmíněného trestu odnětí svobody namísto podmíněného či zamítnutí žádosti o podmínečné propuštění namísto jejímu vyhovění u pachatele ve srovnatelné situaci.

$\mathrm{V}$ případě matematického hodnocení rizikovosti pachatelů je přímá diskriminace jednou z charakteristik celého systému. Systémy matematického hodnocení pracují s kategoriemi jako rasa, etnicita, věk, pohlaví nebo ekonomická skupina. Př́itomnost těchto kategorií zvyšuje z hlediska výpočtu rizikovost pachatelů. Pachatel nemusí v takovém zavdat příčinu zvýšeného rizika svými individuálními vlastnostmi, povahou nebo jinou charakteristikou, kterou může ovlivnit. Diskriminace se bude odehrávat v aplikační rovině, ovšem nebude zapříčiněná interpretací normy, nýbrž reflexí výsledků automatizovaného

77 Čl. 10 Listiny:

„1) Každý má právo, aby byla zachována jeho lidská duistojnost, osobní čest, dobrá pověst a chránèno jeho jméno.

2) Každý má právo na ocbranu pred neopráunèným zasabováním do soukromébo a osobníbo zivivota.

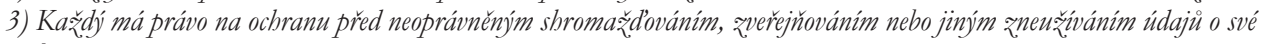
osobè.."“

78 Nález Ústavního soudu ČR ze dne 13. ledna 2010, sp. zn. II. ÚS 1174/09.

79 Ibid. 
rozhodování algoritmu, který bude učením se rekapitulovat výstupy s diskriminačním charakterem. ${ }^{80}$

Přestože EÚLP neumožňuje členskému státu omezit z legitimních důvodů zákaz diskriminace, přiznává tento soud členskému státu u některých důvodů širší možnost uvážení. Je tudíž na zvážení státu, zda rozdílné zacházení uplatní či nikoliv. Toto rozdílné zacházení však musí odůvodnit. Při hodnocení rizikovosti pachatele bývá rozhodováno na základě hodnot, u nichž ESLP uplatňuje prísnější kritéria míry uvážení státu, tedy pohlaví, rasu, národnost nebo etnický původ. Z toho vyplývá, že pokud by bylo stěžovatelem napadeno rozhodnutí státních orgánů, o němž by stěžovatel tvrdil, že porušuje zákaz diskriminace, musel by stát odůvodnit rozdílné zacházení závažnými a objektivními důvody a mezi užitými opatřeními a účelem by musel existovat vztah proporcionality.

Jako porušení čl. 14 EÚLP by ESLP podle našeho názoru shledal odlišné zacházení s obviněným ze strany členského státu, pokud by tomuto obviněnému byl uložen trest odnětí svobody ve větší délce trvání, nebo by byl odsouzen k nepodmíněnému trestu odnětí svobody, či by byla zamítnuta jeho žádost o podmínečné propuštění pouze $z$ důvodů některého $z$ atributů obviněného, který tento nemůže ovlivnit. Ledaže by stát argumentoval odlišným zacházením, které by odůvodňoval širší míru uvážení a u důvodů pohlaví, rasy, národnosti nebo etnického původu objektivními a závažnými důvody pro odlišné zacházení a ESLP by tyto důvody shledal jako legitimní a přiměřené účelu.

Právem, které by bylo $\mathrm{v}$ tomto př́padě porušeno, by bylo právo na spravedlivý proces dle čl. 6 EÚLP. Jako porušení čl. 14 EÚLP bylo shledáno, když stát stížnost na odlišné zacházení ze strany odpovědných osob nejen dostatečně neprošetřil (viz B.H. proti Španélsk $u^{81}$ ), ale i pokud se na diskriminaci aktivně podílel (viz Paraskeva Todorova proti Bulharsku). Lze se proto domnívat, zvláště s ohledem na rozsudek Paraskeva Todorova proti Bulharsku, že by ESLP shledal matematické modely pro hodnocení pachatelů založené na kritériích jako je rasa, etnicita, pohlaví, věk apod. jako porušení čl. 14 EÚLP.

Jako porušení čl. 14 EÚLP by mohl ESLP shledat i postup státu při ukládání výše peněžitého trestu nebo peněžité záruky za vazbu pomocí matematického modelu, kdy by tento model vyhodnotil obviněného jako osobu, u které je tento typ trestu nebo záruky s ohledem na jeho rizikovost možný, nicméně nebral na žretel majetkovou situaci obviněného a všem obviněným by navrhoval peněžitý trest nebo záruku ve stejné nebo podobné výši. Zde by diskriminace spočívala naopak ve stejném zacházení s osobami, pokud by se jejich majetková situace výrazně lišila. Ukládání stejného peněžitého trestu nebo záruky, na které by méně majetní obvinění bud'to v př́ípadě peněžité záruky nedosáhli, nebo by byl peněžitý trest pro nezaplacení nahrazen trestem odnětí svobody, by vyloučilo méně majetné obviněné z těžení z výše uvedených alternativ omezení na svobodě.

80 ROUVROY, 2011, op. cit., s. 33.

81 Rozsudek ESLP ze dne 24. července 2012, stíž. č. 47159/08 ve věci B.H. proti Španělsku. 
Rozhodování na základě takového matematického modelu by ESLP považoval za diskriminační (viz Thlimmenos proti Řecku), pokud by stát tuto praxi objektivně a rozumně nezdůvodnil.

Aby byla stížnost k ESLP nebo žaloba úspěšná, musí stěžovatel, resp. žalobce prokázat, že s ním bylo zacházeno méně př́iznivě než s jinými osobami ve stejné nebo obdobné situaci. Zde opět narážíme na problém transparentnosti rozhodování na základě algoritmu, kdy obviněný nemá povědomí o tom, že k rozhodnutí nebo zásahu došlo na podkladě výsledku generovaného algoritmem. V takovém případě se ani nedozví, že s ní bylo zacházeno méně př́znivě než s jinými osobami ve stejné situaci, jelikož nezná ani hodnoty, se kterými algoritmus pracuje.

\subsection{Právo na spravedlivý proces}

Právo na spravedlivý proces je součástí celé raady lidsko-právních dokumentů. Zároveň prostupuje jako rudá nit’ procesněprávními podústavními předpisy, jejichž ustanovení v určité procesní fázi toto právo konkretizují a specifikují.

Podle čl. 6 odst. 1 EÚLP má každý právo na to, aby jeho záležitost byla spravedlivě, veřejně a $\mathrm{v}$ prriměřené lhůtě projednána nezávislým a nestranným soudem zrrízeným zákonem, který rozhodne o jeho občanských právech nebo závazcích nebo o oprávněnosti jakéhokoli trestního obvinění proti němu. Rozsudek musí být vyhlášen veřejně, avšak tisk a veřejnost mohou být vyloučeny bud' po dobu celého nebo části procesu v zájmu mravnosti, veřejného pořádku nebo národní bezpečnosti v demokratické společnosti, nebo když to vyžadují zájmy nezletilých nebo ochrana soukromého života účastníků, anebo v rozsahu považovaném soudem za zcela nezbytný pokud by, vzhledem ke zvláštním okolnostem, veřejnost řízení mohla být na újmu zájmům spravedlnosti. Druhý odstavec tohoto ustanovení garantuje presumpci neviny. Každý, kdo je obviněn z trestného činu, se považuje za nevinného, dokud jeho vina nebyla prokázána zákonným způsobem. Třetí odstavec čl. 6 dává obviněnému z trestného činu minimální práva, která mu musí být ze strany státu zajištěna. Je to právo na to být neprodleně a v jazyce, jemuž rozumí, podrobně seznámen s povahou a důvodem obvinění proti němu, mít přiměřný čas a možnosti k př́pravě své obhajoby, obhajovat se osobně nebo za pomoci obhájce podle vlastního výběru nebo, pokud nemá prostředky na zaplacení obhájce, aby mu byl poskytnut bezplatně, jestliže to zájmy spravedlnosti vyžadují, vyslýchat nebo dát vyslýchat svědky proti sobě a dosáhnout předvolání a výslech svědků ve svi̊j prospěch za stejných podmínek jako svědků proti sobě a mít bezplatnou pomoc tlumočníka, jestliže nerozumí jazyku používanému před soudem nebo tímto jazykem nemluví.

Součástí práva na spravedlivý proces je i právo na odvolání. Toto právo je součástí Protokolu č. 7 k EÚLP. Každý, koho soud uzná vinným z trestného činu, má právo dát přezkoumat výrok o vině nebo trestu soudem vyššího stupně. Výkon tohoto práva, včetně důvodů, pro něž může být vykonáno, stanoví zákon. Z tohoto práva jsou př́pustné 
výjimky v případě méně závažných trestných činů určených zákonem, nebo pokud byl jednotlivec souzen $\mathrm{v}$ prvním stupni nejvyšším soudem, nebo byl uznán vinným a odsouzen na základě odvolání proti osvobozujícímu rozsudku.

Právo na spravedlivý proces obsahuje v čl. 47 i Listina EU. Každý, jehož práva a svobody zaručené právem Unie byly porušeny, má za podmínek stanovených tímto článkem právo na účinné prostředky nápravy před soudem. Každý má právo, aby jeho věc byla spravedlivě, veřejně a v přiměřené lhưtě projednána nezávislým a nestranným soudem, předem zřízeným zákonem. Každému musí být umožněno poradit se, být obhajován a být zastupován. Bezplatná právní pomoc je poskytnuta všem, kdo nemají dostatečné prostředky, pokud je to nezbytné k zajištění účinného př́istupu ke spravedlnosti.

Čl. 48 Listina EU zakotvuje presumpci neviny a právo na obhajobu. Podle tohoto ustanovení je každý obviněný považován za nevinného, dokud jeho vina nebyla prokázána zákonným zpơsobem. Každému obviněnému je zaručeno respektování práv na obhajobu. Z hlediska algoritmického rozhodování je třeba zmínit ještě ustanovení čl. 49 odst. 3 Listiny EU, podle něhož nesmí být výše trestu nepřiměřená trestnému činu.

Podobně je právo na spravedlivý proces upraveno i v českém právu. Podle čl. 36 Listiny každý se může domáhat stanoveným postupem svého práva u nezávislého a nestranného soudu a ve stanovených př́padech u jiného orgánu. Kdo tvrdí, že byl na svých právech zkrácen rozhodnutím orgánu veřejné správy, může se obrátit na soud, aby přezkoumal zákonnost takového rozhodnutí, nestanoví-li zákon jinak. Z pravomoci soudu však nesmí být vyloučeno přezkoumávání rozhodnutí týkajících se základních práv a svobod podle Listiny. Čl. 37 Listiny zaručuje, že nikdo nesmí být odňat svému zákonnému soudci. Podle tohoto ustanovení má každý právo, aby jeho věc byla projednána veřejně, bez zbytečných průtahů a v jeho prrítomnosti a aby se mohl vyjádřit ke všem prováděným důkazům. Podle čl. 38 Listiny jen soud rozhoduje o vině a trestu za trestné činy. Každý, proti němuž je vedeno trestní řízení, je považován za nevinného, pokud pravomocným odsuzujícím rozsudkem soudu nebyla jeho vina vyslovena. Listina zároveň garantuje obviněnému základní minimální práva na obhajobu podobně jako tomu je v EÚLP.

Jednou z hlavních premis práva na spravedlivý proces je nezávislý soud a nestranný a nezávislý soudce. Nezávislý soud je institucionálním aspektem práva na spravedlivý proces, který je výsledkem dělby moci v demokratickém právním státě na moc výkonnou, zákonodárnou a moc soudní. Moc výkonná ani moc zákonodárná nesmí zasahovat do rozhodovací pravomoci soudů. Obsahem rozhodovací pravomoci soudů je rozhodování $\mathrm{v}$ př́padech stanovených ústavou a zákony. Soudy jako jediné orgány mají pravomoc rozhodovat o vině a trestu za trestné činy. Soudy rovněž rozhodují o podmínečném propuštění z výkonu trestu odnětí svobody, o přeměně trestu odnětí svobody s podmíněným odkladem na nepodmíněný trest odnětí svobody nebo o vazbě obviněného. 
Princip nezávislého a nestranného soudce neznamená pouze absenci vlivu na soudcovské rozhodování ze strany jiných osob. Tento aspekt soudcovské nezávislosti a nestrannosti bychom mohli nazvat aspektem negativním. Výše uvedený princip podle judikatury Ústavního soudu má i svoji pozitivní stránku, kterou tento soud spatřuje v př́tomnosti vlastního svobodného názoru soudce na fakta, která $v$ průběhu řízení vyjdou najevo a na jejich právní posouzení. „Princip nezávislosti soudní moci obsabuje v sobè celou radu aspekttu, ježz ve svém úhrnu maji vytvorit predpoklady pro to, aby soudy mohly plnit své úkoly a povinnosti zejména v oblasti práv a svobod člověke a občana. Pro splnèni podminky nezávislosti je nezbytné, aby soud mobl oprít svá rozhodnuti o svìj vlastni svobodný názor na fakta a na jejich právni stránku, aniž. by mél jakýkoli závazek viici stranám nebo verejným orgánim a aniž by jeho roz̧hodnutí podléhalo prezkoumáni jüným orgánem, který by nebyl stejně nezávislým v uvedeném smyslu. Ústavni garance soudcouské nezávislosti znamená, že nikdo neni oprávnèn zasahovat do ř́zeni prèd soudem a do soudního rozhodováni. Zákon o soudech a soudcich v $\int 79$ tuto zásadu vyjadruje tak, že soudci jsou prí výkonu své funk.ce nezávisli a jsou vázáni pouze zákonem. Jsou povinni vykládat jej podle svého nej-

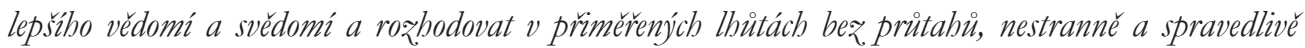
a na zákeladè skutečností zjišrtèných v souladu se zákonem. Nezávislost a nestrannost soudcù nesmí nikedo narušovat. “82 Podobně vnímá nestrannost soudců i Doporučení CM/Rec(2010)12 Výboru ministrů Rady Evropy členským státům nazvané Soudci: nezávislost, efektivita a odpovědnost ze dne 17. listopadu 2010 (dále jen „Doporučení‘). ${ }^{83}$ Podle čl. 1 odst. 5 Doporučení by soudci měli mít neomezenou svobodu rozhodovat věci nestranně podle práva a své interpretace skutečností.

Pavel Molek spatřuje nestrannost soudců ve dvou dalších aspektech. Těmito aspekty jsou absence podjatosti a předsudků soudce ${ }^{84}$ a vědomost účastníka řízení, který konkrétní soudce bude o jeho věci rozhodovat, tedy zabránění rozhodování „sondci bez tváré. 85 Podjatost se vyjadřuje jako vztah k projednávané věci, k účastníkům nebo jejich zástupcům (např. $\int 30$ odst. 1 TŘ). Podjatost soudce může však mít podobu předpojatosti vůči účastníkovi řízení pro jeho národnost, rasu, etnickou příslušnost nebo státní příslušnost. Ve věci Remli proti Francii ${ }^{86}$ rozhodoval ESLP o stížnosti francouzského občana alžírského původu, který tvrdil, že se národní soud nezabýval poznámkou jednoho z prrísedících o svém rasistickém smýšlení. Národní soud se námitkou podjatosti stěžovatele nezabýval. ESLP shledal, že čl. 6 EÚLP byl porušen, jelikož soud, který v konkrétní věci rozhoduje, musí být nestranný. Stejně ESLP rozhodl i v př́padě Sander proti Spojenému

82 Nález Ústavního soudu ze dne 28. dubna 2005, sp. zn. Pl.ÚS 60/04.

83 Doporučení CM/Rec(2010)12 Výboru ministrů Rady Evropy členským státům ze dne 17. listopadu 2010. Rada Evropy [online]. 2003 [cit. 15. 5. 2016]. Dostupné z: https://www.coe.int/t/dghl/standardsetting/ cdcj/CDCJ\%20Recommendations/CMRec(2010)12E_\%20judges.pdf

84 MOLEK, Pavel. Právo na spravedlivýproces. Praha: Wolters Kluwer ČR, 2012, s. 169. ISBN 978-80-7357-748-3.

85 Ibid., s. 171.

86 Rozsudek ESLP ze dne 23. března 1996, stíž. č. 16839/90 ve věci Remli proti Francii. 
královstui ${ }^{87} \mathrm{v}$ němž ve věci podle stěžovatele rovněž rozhodoval porotce s rasistickým smýšlením. Podle ESLP v případě Sander se soudce dozvěděl o tvrzení stěžovatele i to, že kvưli rasovým předsudkům jednoho z porotců hrozí, že obviněný bude odsouzen z důvodu svého etnického původu. ESLP měl za to, že by soudce měl reagovat na rasistické poznámky porotců razantnějším zpơsobem, než pouhým vyžadováním ujištění ze strany porotců, že se tito oprostí od svých předsudků a budou posuzovat projednávanou věc výhradně s ohledem na důkazy. Akceptací tohoto ujištění soudce podle ESLP neposkytl dostatečné záruky pro vyloučení oprávněné pochybnosti o nestrannosti soudu. Z toho podle ESLP vyplývá, že soud, který stěžovatele odsoudil, nebyl z objektivního hlediska nestranný.

Porušením čl. 6 EÚLP nemusí být pouze absence opatření soudu proti pochybnostem o rasistickém smýšlení porotců. Absence opatření proti nestrannému porotci se může týkat i předsudků porotce vůči účastníkovi řízení, který náleží do určité subkulturní skupiny. V př́padě Ekeberg a dalši proti Norsku byla touto skupinou motorkářská skupina Hells Angels. ${ }^{88}$

Nestrannost je podle ESLP dána nejen absencí podjatosti k osobám nebo k věci, nýbrž i co do postojů a předsudků soudců vůči účastníkům řízení z důvodu jejich rasy nebo příslušnosti k určité etnické, sociální nebo sociálně kulturní skupině. Pokud se u soudců nebo u dalších osob zúčastněných na řízení, např. porotců nebo i státních zástupců, vyskytnou rasistické nebo jiné předsudky vưči účastníkovi řízení a soud neučiní potřebná opatření k zajištění nestrannosti rozhodování, je porušeno právo na spravedlivý proces zaručené čl. 6 EÚLP.

Dalším aspektem nestrannosti a nezávislosti soudců, a tím i garancí práva na spravedlivý proces, je absence anonymity soudců. Soudce je sice účastníkům řízení přidělen, nicméně právě aby měl účastník řízení možnost ověřit jeho nezávislost a nestrannost a namítat jeho př́padnou podjatost, musí jeho identitu účastník řízení znát. Pokud totožnost soudce účastník ř́zení nezná, jako v případě Polay Campos proti Peru ${ }^{89}$ ve věci stížnosti Výboru pro lidská práva na praxi, kdy soudci soudili se zahalenou tvárí, je princip nestrannosti a nezávislosti porušen.

Při algoritmickém rozhodování je soudce sice v soudní síni přítomen a sám formálně vynáší rozsudek nebo jiné rozhodnutí, nicméně se při rozhodování neřídí svým pohledem na fakta a jejich zhodnocením, které následně posuzuje v intencích právních předpisů, ale výsledkem generovaným algoritmem, který pracuje s předem nastavenými kategoriemi, které soudce do systému doplňuje. Vlastní svobodný názor soudce se může

87 Rozsudek ESLP ze dne 9. května 2000, stíž. č. 34129/96 ve věci Sander proti Spojenému království.

88 Rozsudek ESLP ze dne 31. července 2007, stíž. č. 11106/04, č. 11108/04, č. 11116/04, č. 11311/04 a č. 13276/04 ve věci Ekeberg a dalši proti Norsku.

89 Rozhodnutí Výboru pro lidská práva ze dne 6. listopadu 1997, stíž. č. 577/1994 ve věci Polay Campos proti Peru. Office of the United Nations High Commissioner for Human Rights [online]. [cit. 15. 5. 2016]. 
projevit pouze v odchýlení se od výsledku, které může však být vázané na konkrétní podmínky, jež nemusí být $\mathrm{v}$ daném prípadě splněny. I když se může soudce v rozhodování od algoritmického výsledku odchýlit, lze mít o vlastním názoru tohoto soudce pochybnosti, nebot', jak jsme již výše uvedli, mají uživatelé systému tendenci respektovat algoritmický výsledek, a to se týče i soudců.

Účastníci řízení nemusí mít povědomí o tom, že se výsledek řízení řídil výstupem generovaným algoritmem, protože neexistuje žádný právní předpis, který by nařizoval soudu účastníkovi řízení tuto skutečnost sdělit. Účastník řízení tedy neví, že takto bylo rozhodováno, a tudíž bude těžko brojit proti nedostatku vlastního svobodného názoru soudce a z toho vyplývající porušení práva na spravedlivý proces.

Pokud je právo na spravedlivý proces účastníka řízení porušeno podjatostí a předsudky soudců, porotců nebo i dalších osob zúčastněných na řízení, lze dovodit, že právo na spravedlivý proces je porušeno i používáním matematických modelů predikujících rizikovost pachatelů s ohledem na možné budoucí páchání další trestné činnosti, at’ již pro účely uložení trestu odnětí svobody s podmíněným odkladem, podmínečné propuštění z výkonu trestu odnětí svobody nebo i v dalších řízeních jako je vzetí do vazby nebo nahrazení vazby slibem obviněného, zárukou důvěryhodné osoby nebo peněžitou zárukou.

To, že v řízení bude rozhodovat předpojatý soudce nelze nikdy vyloučit, nicméně předpojatost je nežádoucí a je dokonce důvodem pro vyloučení takového soudce. Rozdíl mezi předpojatostí jednotlivého soudce a matematického modelu je v tom, že matematické modely prrímo pracují s hodnotami, jako je rasa, etnická prríslušnost, př́slušnost k sociální skupině, pohlaví nebo majetkové poměry, které pokud by se vyskytly jako předsudky a názory u některého ze soudců nebo porotců, byl by takový soudce nebo porotce pro podjatost vyloučen. Pokud by nedošlo k vyloučení takto smýšlejícího soudce nebo porotce, bylo by lze konstatovat, že v rrízení nerozhodoval nestranný soud a že tudíž bylo porušeno právo na spravedlivý proces.

Problematické je, že výše uvedené hodnoty jsou prímo součástí modelu rozhodování. Z údajů o pachatelích, které tito nemohou ovlivnit, jsou generovány výstupy hodnotící jejich rizikovost, resp. nebezpečnost těchto pachatelů pro společnost. Předsudky a podjatost jsou tedy př́mou součástí modelu rozhodování. Jestliže je o pachateli rozhodováno na základě algoritmu, který pracuje s hodnotami, jako je rasa, etnicita, sociální skupina nebo pohlaví, a na těchto hodnotách je založeno rozhodnutí o tomto pachateli, je vždy porušeno právo na spravedlivý proces. Porušení práva na spravedlivý proces je o to závažnější, když se v řízení rozhoduje o omezení na osobní svobodě.

Obrana účastníků řízení je sice možná, ale pokud bude odvolací nebo i dovolací soud pracovat se stejným matematickým modelem, či s jiným modelem, avšak založeným na stejných hodnotách, bude tato obrana pouze formální, jelikož výstup generovaný 
algoritmem bude totožný nebo pouze nepatrně se odchylující. Zde se opět dostáváme k transparentnosti rozhodování na základě algoritmu. Účastník řízení nemusí vědět, že byl pro predikci jeho budoucího chování využit matematický model, a nikoliv individuální posouzení jeho nebezpečnosti soudcem. Z tohoto důvodu si ani nemusí být vědom porušení svého práva na spravedlivý proces.

Existují dva důvody, proč jsme se výše zmínili o problému soudců bez tváře, kteří zůstávají vůči účastníku ř́zení v anonymitě, v souvislosti s algoritmickým rozhodováním, a to i přesto, že účastník řízení jméno a tvář soudce zná. Prvním z důvodů je ten, že soudce, který ŕízení formálně vede a podepisuje se pod rozsudkem nebo jiným druhem rozhodnutí, o účastníkovi řízení fakticky nerozhoduje. Rozhodnutí za něj činí algoritmus. Soudce výsledek algoritmu přebere a zahrne jej do „svého“ rozhodnutí.

Druhým důvodem zmínky o soudcích bez tváře je skutečnost, že existují osoby, které fakticky rozhodují o hodnotách, se kterými algoritmus pracuje. Tyto osoby mohou být inženýry, experty na informační technologie spolu se sociology, probačními úředníky a dalšími osobami, které se zabývají sestavováním modelů lidského chování. Těmto osobami mohou být i soudci, kteří byli přizváni, aby se účastnili vytváření modelu. Pokud se o obviněném rozhoduje na základě takto sestaveného matematického modelu, rozhodnutí je učiněno výše zmíněnými osobami, které se podílely na vytváření modelu, a nikoliv soudcem, jenž vede konkrétní řízení. Z hlediska obviněného jsou vlastně osoby sestavující matematický model soudci bez tváře, jelikož je obviněný souzen na základě hodnot, které tyto osoby do systému vložily a na podkladě kterých algoritmus pracuje. Obviněný tyto osoby nezná a o jejich existenci nemusí mít ani povědomí, přestože jsou to právě tyto osoby, které volbou hodnot a korelací mezi nimi rozhodují o účastníkovi řízení, př́ípadně o omezení na jeho osobní svobodě. Z výše zmíněných důvodů je rozhodování na základě matematického modelu podobné rozhodování soudců se zahalenými tvářemi. Rozdíl je ve skutečnosti, že v případě soudce se zahalenou tvář́ pachatel má vědomost o tom, že je jeho právo na spravedlivý proces, konkrétně aspekt rozhodování nestranným soudcem, porušeno. $V$ případě algoritmického rozhodování o porušení práva na spravedlivý proces neví, jelikož se řízení po formální stránce zdá být v souladu s dokumenty o lidských právech zaručujícími právo na spravedlivý proces.

Právo na spravedlivý proces ve spojení s osobou soudce má v českém právu podobu zákonného soudce, na něhož má podle čl. 38. odst. 1 Ústavy každý právo. Přestože toto právo bývá tradičně vnímáno jako právo obviněného na to, aby o jeho věci rozhodoval soudce prridělený podle předem stanoveného rozvrhu přidělování agendy, není důvod tento aspekt nezmínit i v souvislosti s algoritmickým rozhodováním. Rozhoduje-li o obviněném matematický model vytvořený jinými osobami než je soudce, který má dle rozvrhu danou věc přidělenu, lze dovodit, že algoritmickým rozhodováním bude porušen princip zákonného soudce, a tím i právo na spravedlivý proces. 
Další aspekt práva na spravedlivý proces, který algoritmické rozhodování porušuje, je právo na obhajobu. Lidsko-právní dokumenty vypočítávají celou řadu tzv. minimálních práv na obhajobu. Obviněný, resp. obžalovaný si může zvolit obhájce, nebo mu může být ustanoven a má právo se s ním radit. Obviněnému (obžalovanému) musî být poskytnut dostatečný čas a možnost $\mathrm{k}$ př́pravě obhajoby. Podle ESLP musí mít obhajoba v trestním řízení prostor, aby adekvátním zpơsobem uplatnila své argumenty. Obhajoba podle ESLP funkci strážce zákonného průběhu trestního řízení (Ensslin, Baader, Raspe proti Nèmeckư ${ }^{90}$ ). Aby nebylo do práv garantovaných EÚLP zasaženo, musî být tato práva podle ESLP uplatňována prakticky a efektivně, nikoliv pouze formálně a zdánlivě (např. Airey proti Irsk.u ${ }^{11}$ ).

Jestliže je algoritmické rozhodování rozhodováním na základě určitých hodnot, s nimiž algoritmus pracuje a jež nezávisí na obviněném, je jeho obhajoba pouze formální a zdánlivá. Obviněný má sice $\mathrm{v}$ průběhu ř́zení obhájce, může se s ním radit, může mu být poskytnut dostatečný prostor při přípravě obhajoby i při vlastním řízení. O rozhodnutî ovšem při využití matematického modelu nerozhoduje soudce sám. Rozhodnutí je generované algoritmem a je tudíž, alespoň z části, předem dané, nebot' pro rozhodnutí podstatné údaje o rase, etnicitě, pohlaví, sociálně kulturní skupině, apod. jsou již v systému zaneseny a jsou to právě tyto údaje, na podkladě kterých se vyhodnocuje rizikovost pachatele s ohledem na možnou budoucí recidivu. Pokud je obviněný v řízení zastoupen obhájcem, jež je prrítomen i jednání u soudu, je zákonný požadavek práva na spravedlivý proces formálně naplněn, nicméně obhájce nemá možnost výsledek generovaný algoritmem zvrátit. Ledaže by soudce přesvědčil, že se nemá tímto výsledkem řídit.

\section{Závěr}

Algoritmické rozhodování proniká do rozhodování soudů. Důvodem může být rychlost a efektivita rozhodování, jakož i víra v jeho objektivitu, nebot’ se obecně předpokládá, že algoritmické rozhodování je, na rozdíl od rozhodování člověka, prosto předsudků a zaujatosti. Tato teze se ukázala jako problematická. Algoritmus rozhoduje podle předem zadaných kritérií a hodnot. Tyto hodnoty jsou vybírány lidmi, kteří mohou mezi kritéria zahrnout i kritéria na základě svých předsudků a předpojatostí.

Aby bylo možno rozhodovat automatizovaně, tj. bez zásahů nebo jen s minimálními lidskými zásahy, jež mohou mít podobu např. výběru z několika možných variant na začátku nebo na konci procesu, pracují algoritmy se souborem dat charakterizujících určité minulé okolnosti prrítomné u jiných pachatelů. Jinými slovy, z dat získaných v minulosti jsou vytvářeny profily pachatelů a situací s obecnými znaky typizovanými

\footnotetext{
90 Rozsudek ESLP ze dne 8. července 1978, stíž. č. 7572/76 ve věci Ensslin, Baader, Raspe proti Némecku.
}

91 Rozsudek ESLP ze dne 9. října 1979, stíž. č. 6289/73 ve věci Airey proti Irsku. 
pro tyto osoby a situace. Na základě těchto obecných znaků jsou činěny závěry o okolnostech, které jsou přítomné v době rozhodování.

Pro vyhodnocení míry rizika konkrétního obviněného používá algoritmus profily sestavené na základě osobních údajů pachatele. Některé z těchto údajů mají charakter biometrických údajů, konkrétně biometrických údajů spočívajících v psychologických rysech jednotlivce. Je-li tedy obviněný příslušníkem určité skupiny či vykazuje-li určité psychologické rysy, je systémem automaticky vyhodnocen jako rizikovější či naopak méně rizikový, ačkoliv míra rizika u tohoto obviněného nemusí odpovídat realitě. Algoritmické rozhodování může porušovat dvě základní práva obviněného, kterými jsou právo nebýt diskriminován a právo na spravedlivý proces. Diskriminační je ve vztahu k obviněnému, pokud je s ním zacházeno méně př́iznivě zejména pro jeho rasu, etnickou nebo národnostní prríslušnost, věk, pohlaví nebo prríslušnost k určité sociální skupině. Přestože tato kritéria nemusí být do systému přímo zadávána, lze je dovodit z hodnot, které zprostředkovaně poskytují informaci o výše uvedených skutečnostech.

Do práva na spravedlivý proces je zasaženo právě porušením rovnosti před zákonem. Podmínky pro rozhodnutí soudu jsou sice uvedeny v zákoně, nicméně ve skutečnosti je s různými osobami zacházeno odlišně na základě obecných charakteristik profilu, do něhož jsou systémem zařazeny. Porušení práva na spravedlivý proces je možné spatřovat i v tom, že obviněný nemusí mít vỉbec povědomí o tom, že o něm bylo rozhodnuto nikoliv na základě jeho individuálních charakteristik, ale na základě modelu, který pracuje s hodnotami platnými pro skupinu.

Soudce má rozhodovat nejen nezávisle a nestranně, ale též po zvážení všech skutečností a okolností případu. Pokud je rozhodnutí činěno na základě algoritmu, chybí prostor pro úvahu soudce o individuálních okolnostech jednotlivého př́padu, nebot’ algoritmus, na jehož základě je rozhodováno, pracuje s předdefinovanými hodnotami.

$\mathrm{S}$ ohledem na výše uvedené můžeme proto konstatovat, že algoritmické soudní rozhodování, může představovat zásah do základních lidských práv a svobod. Na rozdíl od zásahu do těchto práv rozhodnutím, které není učiněno na základě algoritmu, je možnost nápravy zásahu u obviněného, do jehož práv bylo zasaženo algoritmickým rozhodnutím, ztížena, a to ze dvou důvodů. Prvním z nich je skutečnost, že rozhodování na základě algoritmu bude považováno za objektivní a nestranné, nebot' u něho zdánlivě chybí lidský prvek znamenající možnost přítomnosti podjatosti a předsudků. Druhým důvodem, proč zásah do základních práv a svobod nemusí být napraven, je absence transparentnosti rozhodování na základě algoritmu. Obviněný si algoritmického rozhodování nemusí být vưbec vědom, pokud nebude právním předpisem stanovena povinnost o rozhodování na základě algoritmu obviněného v řízení informovat. Bez povědomí obviněného o algoritmickém rozhodování nemusí obviněný vůbec rozpoznat, že je do jeho práv zasaženo, nebot’ formálně mohou být všechna jeho práva zachována. 
Algoritmické posuzování pachatele z hlediska jeho možné recidivy je kromě narušení základních práv nežádoucí i ze dvou dalších důvodů. Posuzování budoucího chování algoritmem, při němž se z charakteristik pachatele, jeho sociálního zázemí a př́slušnosti k určité sociální či etnické skupině dovozuje budoucí chování tohoto pachatele, upírá tomuto pachateli možnost vědomě své chování ovlivnit, resp. pachatel takovým rozhodnutím ztratí motivaci ke změně chování po propuštění. Tímto dojde k potvrzení objektivity algoritmické predikce chování osob a k jejímu dalšímu využívání a rozvoji v jiných oblastech práva. Druhým problematickým momentem je ztráta důvěry v lidské rozhodování, ve vlastní úsudek soudce a v jeho intuici. Rozhodování o člověku a jeho budoucnosti se může stát mechanickým do té míry, že funkce soudce nebude k rozhodování ani třeba. Účastnící řízení, o jejichž právech a povinnostech je rozhodováno, tím ztratí právo na lidský zásah, což je ostatně právo, o kterém bychom měli uvažovat jako o důležité součásti práva na spravedlivý proces. 